University of Windsor

Scholarship at UWindsor

\title{
Role of mitochondria in neuronal cell death induced by oxidative stress: Neuroprotection by coenzyme Q(10).
}

\author{
Mallika Somayajulu \\ University of Windsor
}

Follow this and additional works at: https://scholar.uwindsor.ca/etd

\section{Recommended Citation}

Somayajulu, Mallika, "Role of mitochondria in neuronal cell death induced by oxidative stress:

Neuroprotection by coenzyme Q(10)." (2004). Electronic Theses and Dissertations. 3362.

https://scholar.uwindsor.ca/etd/3362

This online database contains the full-text of PhD dissertations and Masters' theses of University of Windsor students from 1954 forward. These documents are made available for personal study and research purposes only, in accordance with the Canadian Copyright Act and the Creative Commons license-CC BY-NC-ND (Attribution, Non-Commercial, No Derivative Works). Under this license, works must always be attributed to the copyright holder (original author), cannot be used for any commercial purposes, and may not be altered. Any other use would require the permission of the copyright holder. Students may inquire about withdrawing their dissertation and/or thesis from this database. For additional inquiries, please contact the repository administrator via email (scholarship@uwindsor.ca) or by telephone at 519-253-3000ext. 3208. 


\section{ROLE OF MITOCHONDRIA IN NEURONAL CELL DEATH INDUCED BY OXIDATIVE STRESS; NEUROPROTECTION BY COENZYME $Q_{10}$}

By Mallika Somayajulu

A Thesis Submitted to the Faculty of Graduate Studies and Research through the Department of Chemistry and Biochemistry in Partial

Fulfilment of the Requirements for

The Degree of Master of Science at

The University of Windsor

Windsor, Ontario, Canada

2004

(C) 2004 Mallika Somayajulu 


$\begin{array}{ll}\begin{array}{l}\text { National Library } \\ \text { of Canada }\end{array} & \begin{array}{l}\text { Bibliothèque nationale } \\ \text { du Canada }\end{array} \\ \begin{array}{l}\text { Acquisitions and } \\ \text { Bibliographic Services }\end{array} & \begin{array}{l}\text { Acquisisitons et } \\ \text { services bibliographiques }\end{array} \\ \begin{array}{l}\text { 395 Wellington Street } \\ \text { Ottawa ON K1A ON4 } \\ \text { Canada }\end{array} & \begin{array}{l}\text { 395, rue Wellington } \\ \text { Ottawa ON K1A ON4 } \\ \text { Canada }\end{array}\end{array}$

Your file Votre référence ISBN: 0-612-92504-8 Our file Notre référence ISBN: 0-612-92504-8

The author has granted a nonexclusive licence allowing the National Library of Canada to reproduce, loan, distribute or sell copies of this thesis in microform, paper or electronic formats.

The author retains ownership of the copyright in this thesis. Neither the thesis nor substantial extracts from it may be printed or otherwise reproduced without the author's permission.
L'auteur a accordé une licence non exclusive permettant à la Bibliothèque nationale du Canada de reproduire, prêter, distribuer ou vendre des copies de cette thèse sous la forme de microfiche/film, de reproduction sur papier ou sur format électronique.

L'auteur conserve la propriété du droit d'auteur qui protège cette thèse. $\mathrm{Ni}$ la thèse ni des extraits substantiels de celle-ci ne doivent être imprimés ou aturement reproduits sans son autorisation.
In compliance with the Canadian Privacy Act some supporting forms may have been removed from this dissertation.

While these forms may be included in the document page count, their removal does not represent any loss of content from the dissertation.
Conformément à la loi canadienne sur la protection de la vie privée, quelques formulaires secondaires ont été enlevés de ce manuscrit.

Bien que ces formulaires aient inclus dans la pagination, il n'y aura aucun contenu manquant.

\section{Canadä}




\section{ABSTRACT \\ ROLE OF MITOCHONDRIAN NEURONAL CELL DEATH INDUCED BY OXIDATIVE STRESS; NEUROPROTECTION BY COENZYME Q 10}

In past research, oxidative stress has been implicated in aging and age related disorders. Cell death caused by oxidative stress has been shown to play an important role in neuro-degenerative diseases. We used differentiated Human Neuroblastoma (SH-SY5Y) and Teratocarcinoma (NT2N) cells as models to study the mechanism of cell death induced by oxidative stress. We observed that differentiated NT2N AND SH-SY5Y cells undewent apoptosis following oxidative stress induced by direct hydrogen peroxide treatment. Morphological, apoptotic features including nuclear condensation and membrane blebbing and biochemical changes including DNA fragmentation and caspase and proteasome activation were evident following oxidative stress. We further investigated the production of Reactive oxygen species and mitochondrial dystunction in the cell under oxidative stress. There was an increase in total ROS produced by the cells after $\mathrm{H}_{2} \mathrm{O}_{2}$ treatment. Furthermore, there was a decrease in the mitochondrial membrane potential and an increase in mitochondrial ROS generation.

$\mathrm{COQ}_{10}$ has been shown to be a potent anti-oxidant and an important component of the mitochondrial respiratory chain. In order to study the effects of CoQ 10 on neuronal oxidative stress, we pre-treated differentiated NT2 and SHSY5Y cells with $\mathrm{CoQ} 10$ for 24 hours prior to $\mathrm{H}_{2} \mathrm{O}_{2}$ treatment. Our results indeed indicated that pre-treatment with $\mathrm{COQ}_{10}$ inhibited total ROS production and 
reduced caspase-3 activity and proteasome activity considerably. Moreover, $\mathrm{COQ}_{10}$ maintained a mitochondrial membrane potential even following oxidative stress and reduced the amount of ROS produced by mitochondria. My study suggests that water soluble $\mathrm{CoQ}_{10}$ not only acts as an anti-oxidant but also stabilizes the mitochondrial membrane during oxidative stress. We found that $\mathrm{CoQ}_{10}$ also offered neuroprotection when neuronal cells were subjected to oxidative stress induced using environmental toxin paraquat. Taken together, the results of this study suggested that water soluble $\mathrm{CoQ}_{10}$ can prevent mitochondrial collapse and block neuronal a poptosis. Thus $\mathrm{CoQ}_{10}$ has a great potential for chemotherapeutic intervention in neurodegenerative diseases. 
Dedicated to my parents 


\section{ACKNOWLEDGEMENTS}

I wish to express my deep gratitude towards my supervisor, Dr. Siyaram Pandey, for accepting me as his student and giving me a chance to study here at the University of Windsor. I would also like to thank him for all his guidance throughout the past two years, for all the good times that we have had and for all the help and support he gave me while I was new here and learning to adjust to a new city and culture.

My sincere thanks to Dr. Lee and Dr. Zielinski for being on my committee, for all the valuable suggestions, advice, encouragement, and support.

I am very thankful to Dr. Mutus, Dr. Lee and Dr. Ananvoranich for allowing me to use some of their instrument facilities for this work. I am very grateful to Jafar, who helped me learn many of the techniques and also for sharing his knowledge and experience. I am also very thankful to Sarah for all her help and support. I would also like to thank Christopher, Danielle, Natasha, Daisy and Aubri. Thanks to Yit, for all her help and support. I am also thankful to Paul for all his help and suggestions. I would also like to thank Monique, Arun, Shane, Ju, Dana, Eck, Jiyun, Anupama, Ritu, Ahmed and Tom for their kindness and assistance.

I would take this opportunity to thank my friends Christina, Inga, and Fatema for all the care, encouragement, help and support especially when I miss home and get cranky. I am also very thankful to all the people in the chemistry 
and biochemistry graduate office for all their help and the University of Windsor for the financial support throughout the past two years.

Finally, I want to thank my family for their constant encouragement and support. 
$\begin{array}{lc}\text { ABSTRACT } & \text { i } \\ \text { DEDICATION } & \text { iii } \\ \text { ACKNOWLEDGEMENTS } & \text { iv } \\ \text { LIST OF FIGURES } & \text { ix } \\ \text { LIST OF ABBREVATIONS } & x i\end{array}$

\section{CHAPTER 1 \\ INTRODUCTION}

1.1. Apoptosis

1.2. The biochemical mechanism of apoptosis 4

1.2.1. The extrinsic pathway 4

1.2.2. The intrinsic pathway 4

1.3. Proteases involved in apoptosis 6

1.4. Role of mitochondria in apoptosis 8

1.5. The Bcl-2 family: activators and inhibitors of apoptosis 11

1.6. Oxidative stress 12

1.7. Oxidative stress by neurotoxins 13

1.8. Anti-oxidants 14

1.8.1. Coenzyme $Q_{10}$

1.9. Cell Lines

1.9.1. Human teratocarcinoma cells

1.9.2. Human neuroblastoma cells 19

Objectives of this study

\section{CHAPTER 2 \\ MATERIALS AND METHODS}

2.1. Chemicals and supplies 21

2.1.1. Cell lines $\quad 21$

2.1.2. Media 21

2.1.3. Coenzyme $Q_{10}$

2.1.4. Other chemicals 22

2.2. Apparatus and instrumentation 22

2.3. Cell Culture 23

2.3.1. Human teratocarcinoma cells 23

2.3.2. Human neuroblastoma cells 24

2.4. Experimental treatments 24

2.4.1. Oxidative stress 24

2.4.1.1. $\mathrm{H}_{2} \mathrm{O}_{2}$ treatment $\quad 25$

2.4.1.2. Paraquat treatment 25

2.5. Cellular staining and microscopy 25

2.6. Comet assay 26

2.7. Total cell lysate 27

2.8. Protein estimation 27 
2.5. Cellular staining and microscopy 25

2.6. Comet assay 26

2.7. Total cell lysate 27

2.8. Protein estimation 27

2.9. Proteasome and caspase-3 activity 27

2.10. Reduced Glutathione (GSH) assay 28

2.11. Lipid peroxidation assay 29

2.12. Measurement of reactive oxygen species (ROS) 30

2.13. Measurement of ROS production from isolated mitochondria 30

2.14. Mitochondrial membrane potential 32

2.15. ATP determination 32

CHAPTER 3

RESULTS

3.1.1. Differentiation of NT2 and SH-SY5Y cells 33

3.1.2. Oxidative stress caused by hydrogen peroxide induces apoptosis 33 in differentiated neuronal cells

3.1.3. Generation of ROS by NT2 N cells following oxidative stress 43

3.1.4. Neuroprotective effects of water soluble $\mathrm{COQ}_{10}$ on neuronal 43 cells after hydrogen peroxide treatment

3.1.5. Oxidative stress causes an increase in lipid peroxidation which is 46 decreased in the presence of $\mathrm{COQ}_{10}$

3.1.6. $\mathrm{COQ}_{10}$ pre-treatment results in maintaining GSH levels following oxidative stress

3.1.7. CoQ 10 reduces the activity of caspase-3 and proteasome 50

3.1.8. Oxidative stress causes mitochondrial dysfunction 50 and increased hydrogen peroxide from mitochondria; inhibition by $\mathrm{COQ}_{10}$

3.1.9. CoQto prevents the collapse of mitochondrial membrane potential 53

3.1.10. CoQ10 restores ATP production in cells under oxidative stress 55

3.2.1. Paraquat induces oxidative stress that can induce apoptosis in $\quad 59$ differentiated neuronal SH-SY5Y cells

3.2.2. Pre-treatment with water soluble CoQ10 protects cells from 
paraquat induced apoptosis

3.2.3. Paraquat induces oxidative stress in differentiated SH-SY5Y cells

\section{CHAPTER 4 \\ DISCUSSION}

4.1. NT2 and SH-SY5Y cells as neuronal models

4.2. Induction of apoptosis by external oxidative stress 66

4.3. Oxidative stress causes mitochondrial dysfunction 67

4.4. Neuroprotection offered by $\mathrm{CoQ}_{10}$ prevents mitochondrial dysfunction 68 and rescues cells from oxidative stress

4.5. Mechanism of CoQ 10 neuroprotection 70

4.6. Neuroprotection by $\mathrm{CoQ}_{10}$ against paraquat toxicity 70

$\begin{array}{ll}\text { FUTURE PROSPECTIVES } & 73\end{array}$

$\begin{array}{ll}\text { REFERENCES } & 75\end{array}$

VITAAUCTORIS 96

viii 


\section{LIST OF FIGURES}

FIGURE

Figure 1

Figure 2

Figure 3

Figure 4

Figure 5

Figure 6

Figure $7 \mathrm{~A}-\mathrm{C}$

Figure $7 D-E$

Figure 8A-C

Figure 8 D-F

Figure 9A-C

Figure 9D-F

Figure 10

Figure 11

Figure 12A
TITEE

The two different forms of cell death: Apoptosis and Necrosis

The extrinsic pathway in apoptosis

5

The intrinsic pathway in apoptosis

7

Components of the permeability transition pore

Structural similarities between paraquat and MPP ${ }^{+}$

The different forms of $\mathrm{CoQ}_{10}$

Morphology of NT2 cells during differentiation

Morphology of SH-SY5Y cells during differentiation

hydrogen peroxide treatment

hydrogen peroxide treatment

hydrogen peroxide treatment

hydrogen peroxide treatment

CoQ 10 rescues cells from undergoing apoptosis after hydrogen peroxide treatment

by hydrogen peroxide treatment in NT2N cells after hydrogen peroxide treatment 
Figure 12B

Figure 13

Figure 14

Figure 15A

Figure 15B

Figure 16

Figure 17A-C

Figure 17D-F

Figure 18

Figure 19

Figure 20

Figure 21

Figure 22
Production of total reactive oxygen species in differentiated SH-SY5Y cells after hydrogen peroxide treatment

Lipid peroxidation in differentiated SH-SY5Y

Cells after hydrogen peroxide treatment

GSH levels in NT2N cells after hydrogen peroxide treatment

Caspase-3 activation following hydrogen peroxide treatment

Proteasome activity after hydrogen peroxide treatment

Production of mitochondrial reactive oxygen species after hydrogen peroxide treatment

differentiated SH-SY5Y cells following hydrogen peroxide treatment

Mitochondrial membrane potential in differentiated NT2 astrocytes following hydrogen peroxide treatment

Mitochondrial ATP production in SH-SY5Y cells after hydrogen peroxide treatment

Morphology of SH-SY5Y cells after paraquat treatment paraquat treatment

DNA degradation after paraquat treatment 


\section{LIST OF ABBREVIATIONS}

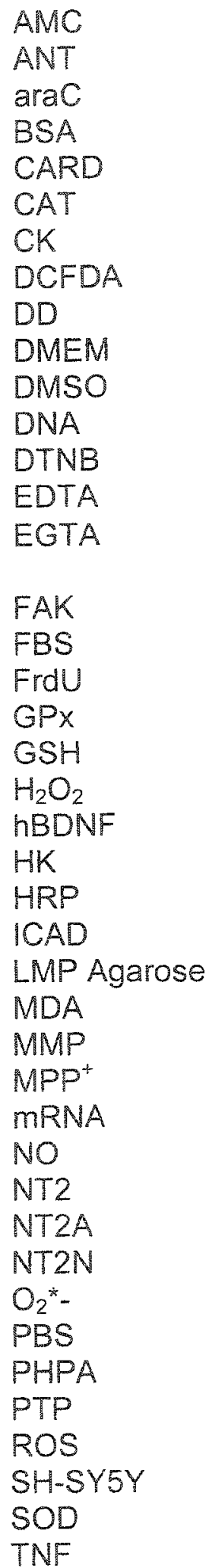

amino methyl coumarin

adenosine nucleotide transporter

cytosine arabinoside

bovine serum albumin

caspase recruitment domain

catalase

creatine kinase

2', 7'-dichlorofluorescein diacelate

death domain

Dulbeco's Modified Eagle Medium

dimethylsulfoxide

deoxyribo nucleic acid

5, 5'-dithio-bis (2-nitrobenzoic acid)

ethylenediaminetetra-acetic acid disodium salt

ethylene glycol-bis ( $\beta$-amino methyl ether) $N$,

N, N', N'tetra acetic acid

focal adhesion kinase

fetal bovine serum

fluorodeoxyuridine

glutathione peroxidase

reduced glutathione

hydrogen peroxide

human brain derived neurotrophic factor

hexokinase

horse radish peroxidase

inhibitor of caspase activated DNase

low melting point agarose

Malonaldehyde

mitochondrial membrane permeability

$\mathrm{N}$ methyl, 4-phenyl pyridinium

messenger RNA

nitric acid

human teratocarcinoma

differented human astrocytes

differentiated human neurons

superoxide anion radical

phosphate buffer saline

para-phenyl acetic acid

permeability transition pore

reactive oxygen species

human neuroblastoma

superoxide dismutase

tumour necrosis factor 
Urd

VDAC

$\triangle H_{m}$ uridine

voltage dependent anionic channel

mitochondrial membrane potenitial 


\section{INTRODUCTION}

Excessive loss of neuronal cells due to programmed cell death has been reported in several neurodegenerative diseases like Alzheimer's disease, Parkinson's disease, ischemia and amyotrophic lateral sclerosis (Beal 1999, Behl 1999, Fiskum et al., 1999, Piantadosi et al., 1996, Coyle et al., 1993, Siesjo et al., 1993, Traystman et al., 1991). In most of these diseases, oxidative stress has been implicated to cause apoptosis. Neuronal cells are very sensitive to free radicals partly due to the high rate of oxygen consumption. Neurons are post mitotic tissues and hence once lost, cannot be re generated. A severe loss in neurons could lead to impaired brain function and affect memory and cognition.

\subsection{Apoptosis}

Cell d eath plays a significant role not only in the d evelopment of multi-cellular organisms, but also in maintaining tissue homeostasis. Kerr et al. proposed that there are two distinct cell death pathways that cells may undergo: one pathological and the other physiological. They recognized these two distinct morphological forms of cell death and coined the terms 'necrosis' for the accidental cell death and 'apoptosis' for the programmed cell death (Kerr et al., 1972). Necrotic cell death is an uncontrolled process, which may be induced by factors such as physical damage, injury, toxic agents, extreme heat and pressure. Some of the prominent morphological features of necrosis include an increase in cell volume, causing cells to rupture and releasing cellular contents such as enzymes into the intercellular milieu (Gores et al., 1990). 
This can further cause tissue damage by affecting neighbouring cells or by attracting proinflammatory cells to the affected area and causing necrotic cells to be engulfed (Haslett 1992). The biochemical characteristics of necrosis are random degradation of DNA and random proteolysis of proteins.

Apoptosis differs from necrosis in that it is a highly orchestrated form of cell death (Figure 1). Physiological stimuli such as lack of growth factor and hormones, or oxidative stress DNA damaging agents (such as ultra-violet radiation), chemotherapeutic drugs may induce the apoptotic cell death pathway. Cells have a withered and shrunken appearance and they do not adhere to the neighbouring cells. Nuclear condensation is simultaneously followed by membrane blebbing and formation of apoptotic bodies occurs. Neighbouring cells then phagocytose these apoptotic cells. As the plasma membrane remains intact when the cell dies, there is no inflammation. DNA degradation of cells undergoing apoptosis also tends to be very systematic. In addition, there is a rapid alteration in the organization of phospholipids in most cell types leading to the exposure of phosphatidyl serine on the cell surface.

Apoptosis plays an important role in embryo development and in the adult animal during tissue turnover or at the end of an immune response (Ashkenazi et al., 1998). It also acts as a safe guard against growth of cells carrying mutations and which are potentially capable of becoming cancerous. The significance of apoptosis in maintaining the normal functioning of the body is demonstrated when it malfunctions. If there is decreased apoptosis, it results in autoimmune diseases and cancers, causing cells to grow uncontrollably. On the other hand, 
Figure 1. The two different forms of cell death: Apoptosis and Necrosis

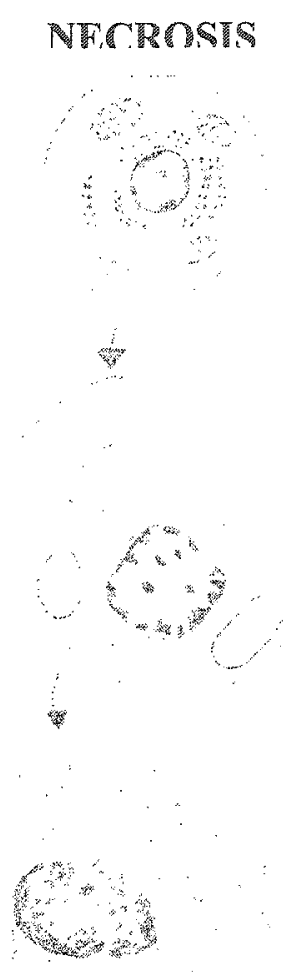

APOPTOSTS

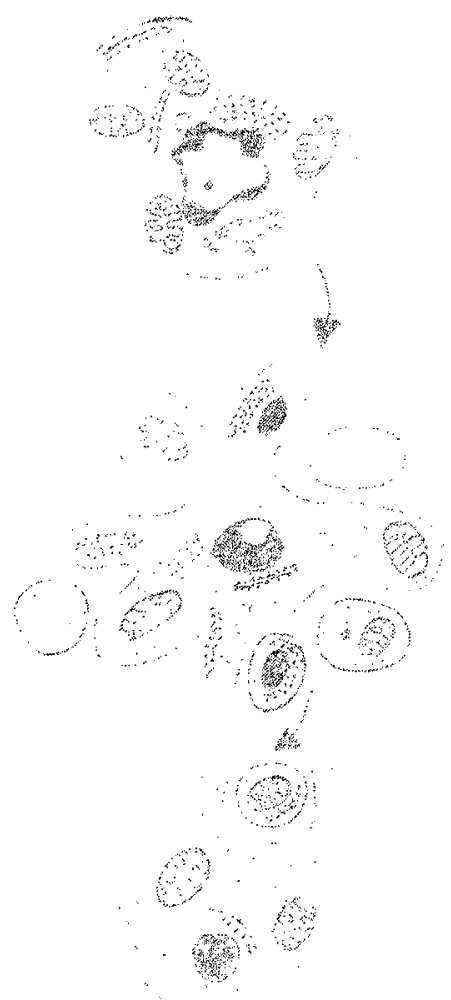

Cell death can be of two types: apoptosis and necrosis. Apoptosis is marked by nuclear condensation, cell shrinkage, membrane blebbing and formation of apoptotic bodies which are engulfed by neighbouring cells. Necrosis is accompanied by random DNA degradation and an increase in cell volume ultimately causing the cell to burst, spilling its contents into the inter-cellular milieu. 
excessive cell death may result in stroke damage and neurodegenerative diseases and AIDS.

\subsection{The biochemical mechanism of apoptosis}

Two pathways causing apoptosis have been well established. The extrinsic pathway employs the death ligand induced activation of death receptors resulting in the activation of initiator caspases (Ashkenazi et al., 1998). In the intrinsic pathway, apoptotic signals affect the mitochondria such that apoptogenic factors are released into the cytoplasm.

\subsubsection{The extrinsic pathway}

Death receptors are cell surface receptors belonging to the tumour necrosis factor receptor (TNF) family. Death receptors contain a homologous cytoplasmic sequence called the death domain (DD) (Tartaglia et al., 1997). These $\mathrm{DD}$ are responsible for recruiting adapter molecules, which in turn recruit caspases to the receptor complex (Figure 2). In most cases, caspase-8 is recruited. Once activated, caspase-8 activates effector caspase, caspase-3. Caspase-8 can also cleave Bid, a pro-apoptotic protein, which translocates to the mitochondria and affects the mitochondrial membrane potential by having pronounced effects on the other pro-apoptotic proteins.

\subsubsection{The intrinsic pathway}

This pathway is also known as the mitochondrial pathway. The role of mitochondria in the activation of caspases is implicated in various studies (Zou et al., 1999, Li et al., 1997, Zou et al., 1997). Different types of stress such as oxidative stress, DNA damage, etc. can result in the leaking of cytochrome $c$ 
Figure 2. The extrinsic pathway in apoptosis

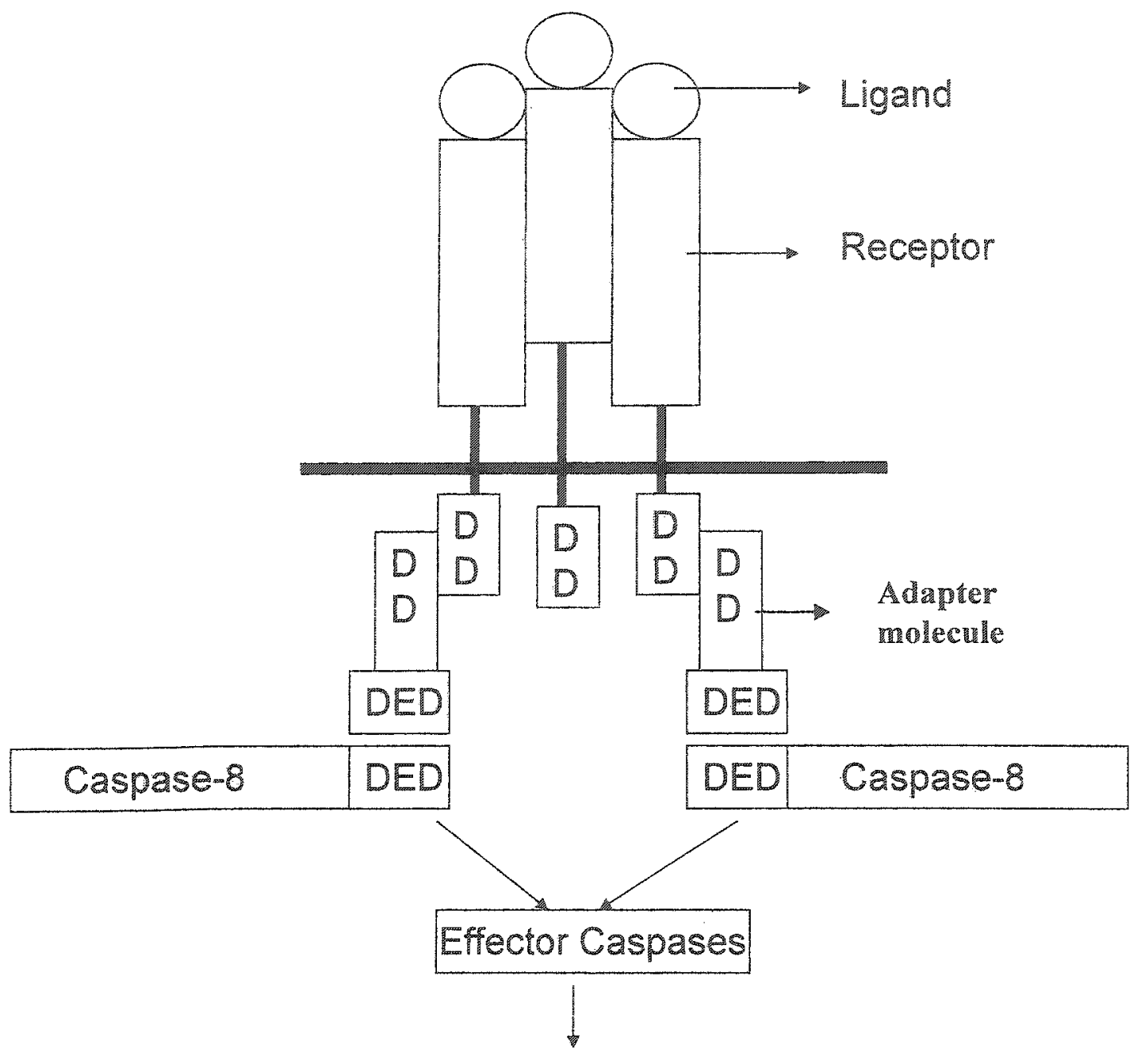

APOPTOSIS

The binding to the ligands to the death receptors causes the recruitment of adapter molecules via death domains (DD). These adapters in turn recruit initiator caspases such as caspase-8 via death effector domains (DED). Upon activation of caspase-8, effector caspases like caspase-3 are activated. Activation of effector caspases ultimately leads to apoptosis. 
from the inner membrane space of the mitochondria into the cytoplasm (Kroemer et al., 1997). Cytochrome $\mathrm{c}$ binds to Apaf-1 in the presence of ATP causing a conformational change in Apai-1 allowing it to bind to procaspase-9 via the caspase recruitment domains (CARD) present in both the molecules. Aggregation of procaspase-9 leads to auto-proteolysis and activation of downstream caspases like caspases-3 (Figure 3 ). The role of mitochondria in apoptosis is described in detail in the later section.

\subsection{Proteases involved in apoptosis}

There exists a special machinery to execute apoptotic cell death. The central component of this machinery is a proteolytic system called caspases. Recent studies have shown the activation of another enzyme pathway called the ubiquitin-proteasome pathway that mediates protein degradation is activated during apoptosis.

Caspases are a very important component of the apoptotic pathway. Enzymes belong to a family of cysteine specific proteases (Thornberry et al,, 1998). These enzymes use cysteine as the nucleophilic group for substrate cleavage and cleave peptide bonds on the carboxyl side of aspartic acid residue (Earnshaw et al., 1999, Nicholson 1999, Cohen 1997, Villa et al., 1997). At least 14 caspases have been identified in mammals. They are expressed as zymogens and require proteolytic processing between domains to form the mature protein. Upon initiation of an apoptotic signal, multiple caspases are activated via caspase cascades in the cell (Macfarlane ef al., 1997, Casciola-

$$
-6-
$$


Figure 3. The intrinsic pathway in apoptosis

Death signals
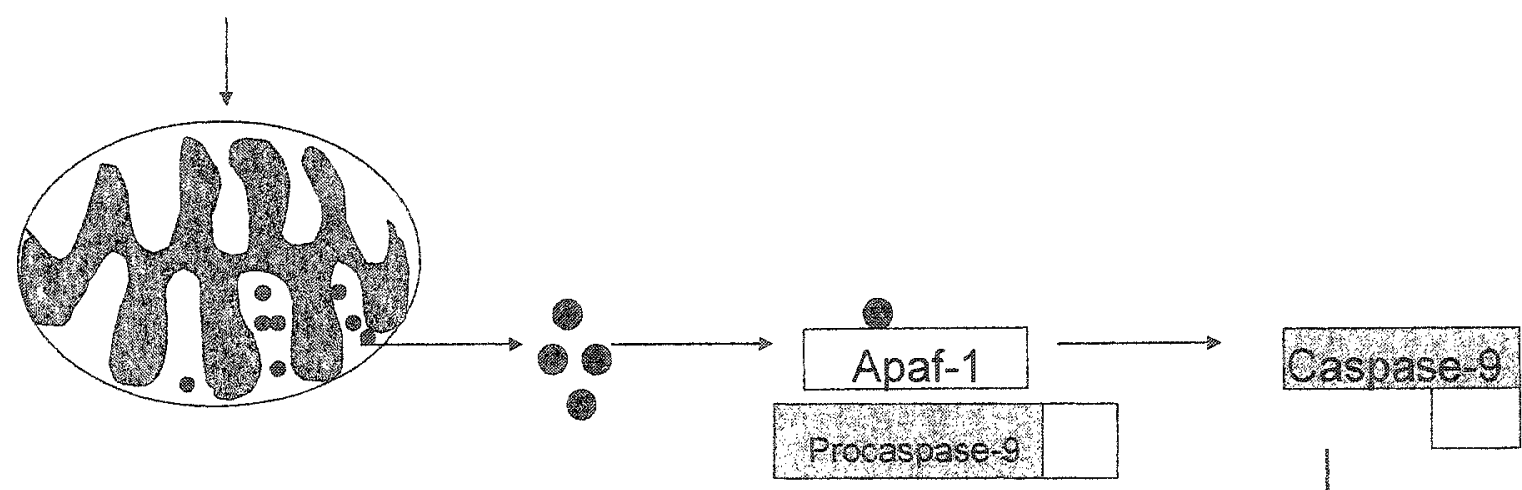

Apoptosis
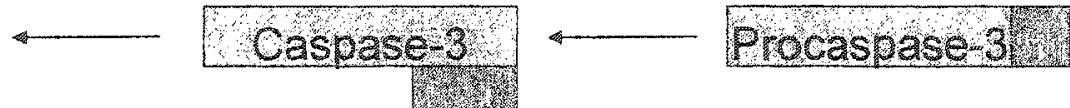

Release of apoptogenic factors such as cytochrome $c$ from the mitochondria leads to the activation of initiator caspases. Apaf-1 undergoes a conformational change upon cytochrome $\mathrm{c}$ binding and binds to procaspase-9, and activates it. Caspase-9 then causes the activation of effector caspases such as caspase-3. Caspase- 3 inactivates important proteins ultimately leading to the apoptosis. 
Rosen et al., 1996, Casciola-Rosen et al., 1994). Caspases can be divided into two categories depending on their order of activation. The caspases that are activated first in the cascade are called initiator caspases such as caspase-8. Upon activation, these initiator caspases activate the effector caspases like caspase- 3 that execute the apoptotic program.

One of the major roles of caspases is to inactivate the proteins that protect cells from apoptosis like the cleavage of the inhibitor of caspase activated DNase (ICAD) (Enari et al., 1998, Liu et al., 1997). ICAD is an inhibitor of a nuclease responsible for DNA degradation called Caspase activated DNase (CAD). Cleavage of ICAD results in the activation of CAD, which enters the nucleus and degrades the DNA. Some of the other functions of caspases include disassembly of cell structures like destruction of nuclear lamina (Takahashi et al., 1996, Orth et al., 1996), reorganizing proteins such as gelosin (Kothakota et al., 1997), focal adhesion kinase (FAK) (Wen et al., 1997), etc. which are involved in cytoskeleton leading to deregulation of their activity, inactivation of proteins involved in DNA repair and replication and mRNA splicing (Cryns et al., 1998, Enari et al., 1998).

Recent studies have shown protein degradation by the ubiquitinproteasome pathway during apoptosis. The proteasome pathway is involved in the general degradation of damaged, non-functional and unwanted proteins in the cells (Rodgers et al., 2002). Activation of proteasome has been observed during serum deprivation-induced apoptosis (Pandey ef al., 2003). 


\subsection{Role of mitochondria in apoptosis}

Mitochondria play a very important role in apoptosis (Desagher et al, 2000 Green et al., 1998). Mitochondria control apoptosis at various levels, including maintenance of ATP production (Leist et al., 1997), mitochondrial membrane potential and mitochondrial membrane permeability for the release of apoptogenic factors from the inter membrane space of the mitochondria into the cytosol (Kroemer et al., 2000, Vayssière et al., 1994, Zoratti et al., 1995). During apoptosis, the changes in the mitochondrial membrane potential have been associated with the opening of the mitochondrial permeability transition pore (MPTP) (Halestrap et al., 2000, Lemasters et al., 1998).

The permeability transition pore is a large multi protein complex that spans the mitochondrial membranes, creating a channel between the cytosol and the mitochondrial matrix (Harris et al., 2000, Zoratti et al., 1995). The components of this channel include a voltage dependent anionic channel (VDAC), adenosine nucleotide transporter (ANT), the benzodiazapine receptor, hexokinase (HK), creatine kinase (CK) and cyclophilin D (Zoratti et al., 1995) (Figure 4). The opening of the permeability transition pore (PTP) depends on the mitochondrial membrane potential and the binding of different molecules. Marked increase in the intra mitochondrial $\mathrm{Ca}^{+2}$ levels, increased oxidative radical levels, partial failure of respiratory complexes, either individually or together can produce a fall in mitochondrial membrane potential $\left(\Delta \Psi_{m}\right)$ (Richter 1993).

The opening of the PTP dissipates remaining proton gradient across the mitochondrial membrane and further reduces $\Delta \Psi_{m}$. Several factors have been 
Figure 4. Components of the permeability transition pore

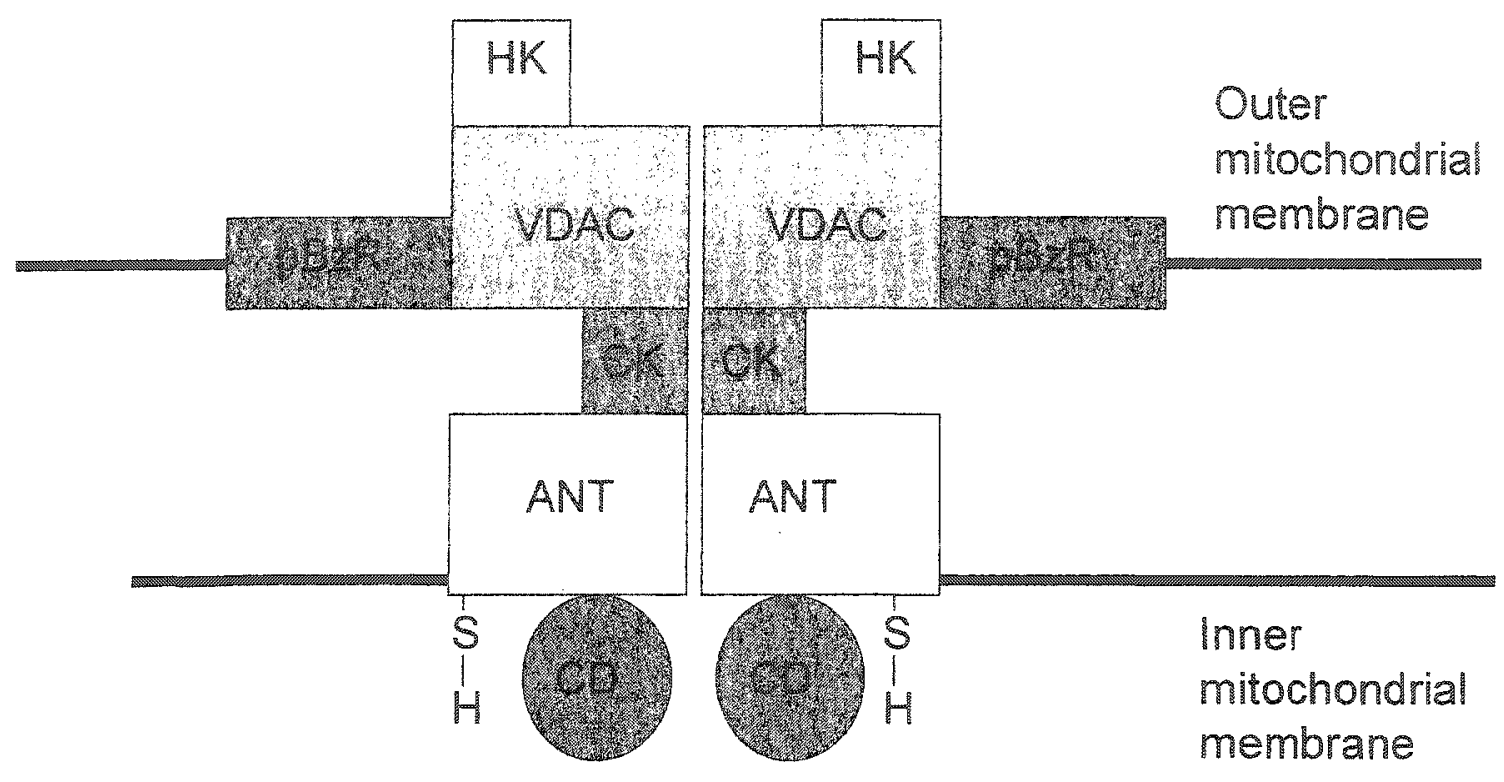

The permeability transition pore is a channel between the cytosol and the mitochondrial matrix. The components of this channel include a voltage dependent anionic channel (VDAC), adenosine nucleotide transporter (ANT), the benzodiazapine receptor, hexokinase $(\mathrm{HK})$, creatine kinase $(\mathrm{CK})$ and cyclophilin D. The opening of the pore causes a loss in the potential and allows the release of apoptogenic substances from the mitochondria into the cytoplasm. 
shown to influence the opening or the closure of PTP. Pore opening is favoured by events which include cross linking of protein thiols by oxidative agents, high levels of intracellular $\mathrm{Ca}^{+2}$, release of glutathione from the mitochondria (Hirsch et al., 1997) and increased ROS levels in the mitochondrial matrix (Chernyak et al., 1996). However, binding of Bcl-2 to the PTP favours PTP closure.

\subsection{The Bcl-2 family: activators and inhibitors of apoptosis}

The Bcl-2 family of proteins plays an important role in regulating apoptosis. This family of proteins can be divided into two functional groups: the a nti-apoptotic (Bcl-2, Bcl-xl, Bcl-w) and pro-apoptotic group (Bax, Bid, Bak, Bim). One of the key features of this family is that the members share sequence homology (Hunter et al., 1996, Chitienden et al., 1995, Yin et al., 1994). Upon a poptotic stimuli, many pro-apoptotic proteins tanslocate from the cytoplasm to the mitochondria (Gross et al., 1999, Huang et al, 1998), undergo a conformational change and oligomerize within the mitochondrial membranes (Leist et al., 2001, Gross et al., 1999, Goping et al., 1998). The pro and anti-apoptotic proteins can interact with each other to form homodimers and heterodimers. The anti-apoptotic members of the Bcl-2 family can inhibit the translocation and homodimerization of proapoptotic Bcl-2 family members. For example Bcl-2 forms heterodimers with Bax, preventing the formation of Bax: Bax homodimers thereby interfering with the ability of Bax to increase MMP (Benedict et al., 2000). The anti-apoptotic members of the Bcl-2 family shut off the apoptotic signal cascade upstream of effector caspase activation by preventing the release of cytochrome $c$ from the 
mitochondria (Boulakia et al., 1996, Chinnaiyan et al., 1996, Shimizu et al., A, 1996, Shimizu et al., B, 1996).

\subsection{Oxidative stress}

Oxidative stress refers to the undue oxidation of biomolecules leading to cellular damage, and it is carried out by reactive oxygen species (ROS). Various neurodegenerative disorders and syndromes are associated with oxidative stress (Behl 2002).

ROS include a number of reactive molecules derived from oxygen and are generated during normal metabolic processes and in response to various stimuli (Fleury et al., 2002, Frodovich 1978). Mitochondria are the major source of ROS in the cell. Levels of ROS generated during "leaky" mitochondrial respiration are not negligible: the amount of $\mathrm{H}_{2} \mathrm{O}_{2}$ and other $\mathrm{ROS}$ produced by brain mitochondria can reach $5 \%$ of $\mathrm{O}_{2}$ metabolized (Arnaiz et al., 1999, Chance et al., 1979). The mitochondrial electron transport chain produces ROS at Complex-1 and Complex- $\| 11$.

Much of the data a re in agreement $w$ ith the hypothesis that increase in ROS is a consequence of the impaiment of mitochondrial respiratory chain (Fleury et al., 2002). Stepwise reduction of molecular oxygen occurs via one electron transfer leading to the formation of ROS like superoxide and hydrogen peroxide (see below). $\mathrm{H}_{2} \mathrm{O}_{2}$ is not a free radical but can penetrate cell membranes making it very toxic to the cell. It acts as an intracellular signaling molecule (Rhee 1999, Sunderesan et al, 1995). $\mathrm{H}_{2} \mathrm{O}_{2}$ can give rise to an $\mathrm{OH}$ * 
radical which is probably capable of causing more damage than any other ROS (Betteridge 2000, Halliwell 1987). The superoxide radical can also react with nitric oxide (NO) to form peroxynitrite, which is highly reactive and cytotoxic.

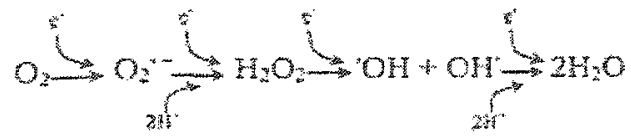

ROS can react with different biomolecules like proteins, DNA and lipids. In vitro studies have revealed that ROS can react with several amino acid residues leading to less active enzymes and malfunction of proteins (Butterfield et al., 1998, Steinberg 1997). ROS can cause modifications in DNA leading to mutagenesis. Studies have shown a high prevalence of cancer in individuals exposed to oxidative stress (Marnett 2000, Mates et al., 1999). ROS has also been shown to target mitochondrial DNA (Shoji et al., 1995). In many cases apoptosis is mediated by ROS (Kamata et al., 1999). Recent studies have indicated that ROS could be responsible for decrease in Bcl-xI mRNA (Carmody et al., 2000). Moreover ROS can also lead to the activation of cell death mediators (Burdon 1996, Burdon 1995) and also cause lipid peroxidation (Butterfield et al., 1998, Steinberg 1997).

\subsection{Oxidative stress by neurotoxins}

Paraquat (1, 1'-dimethyl-4, 4' bipyridinium) is a non selective herbicide widely used for broadleaf weed control (Suntres 2002) has been found to selectively kill nigrostriatal dopaminergic neurons in animal models. Paraquat is 
very toxic and can be lethal to both animals and humans upon acute exposure (Onyon et al., 1987). The structure of paraquat resembles closely to the structure of $\mathrm{N}$ Methyl, 4-phenyl pyridinium $\left(\mathrm{MPP}^{+}\right)$, which is a dopaminergic neurotoxin (Shimizu at al., 2001). Due to the similarity in structure with MPP (Figure 5), there may be a possible role of paraquat exposure in the development of neurodegenerative disease (Corasoniti et al., 1998). Moreover, studies have revealed a strong co relation between the amount of paraquat used and Parkinson's disease (Liou et al., 1997, Liou et al., 1996, Morano et al., 1994). Though research has shown that paraquat can cause oxidative stress, the mechanism by which paraquat induces cell death is still not clearly understood. Further studies are essential in order to determine the mechanism of paraquat induced cell death.

\subsection{Anti-oxidants}

Oxidative metabolism in brain tissue as in all cells occurs in mitochondria. During oxidative phosphorylation, a finite amount of $\mathrm{O}_{2}$ is left partially reduced as the superoxide anion $\left(\mathrm{O}_{2}{ }^{*}\right)$. ROS emanating from within the cell can threaten homeostasis if they are not appropriately resolved. Local levels of ROS at any given time will depend not only on the rate of generation, but also on the efficacy of the antioxidant network. Neuroprotective antioxidants are considered a promising approach to slowing the progression and limiting the extent of neuronal cell loss in neurodegenerative disorders. 
Figure 5. Structural similarities between paraquat and MPP*

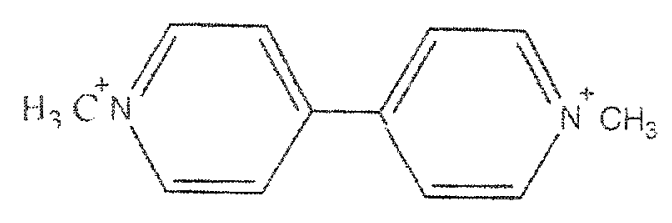

Paraquat

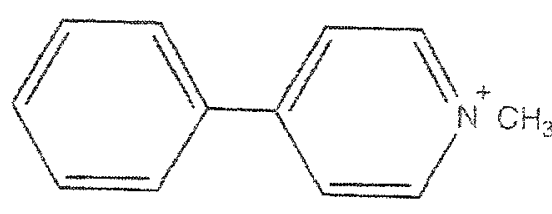

MPPt

The structure of paraquat resembles that of $\mathrm{N}$ methyl, 4-phenyl pyridinium $\left(\mathrm{MPP}^{+}\right) . \mathrm{MPP}^{+}$is a dopaminergic neurotoxin. Paraquat exposure has been linked to Parkinson's disease. 
Under normal physiological conditions, free radicals are countered by various antioxidant defenses; enzymatic and non-enzymatic. Superoxide dismutase (SOD), glutathione peroxidase (GPX), and catalase (CAT) are among the first line of defense against oxygen toxicity. SOD converts $\mathrm{O}_{2}{ }^{*}-t_{0} \mathrm{H}_{2} \mathrm{O}_{2}$, which is further converted to $\mathrm{H}_{2} \mathrm{O}$ with the help of GPX and CAT. SOD inhibits

${ }^{*} \mathrm{OH}$ production. It is considered to be the first line of defense against $\mathrm{O}_{2}$ toxicity (Ray et al., 2002).

The non-enzymatic antioxidants like glutathione (GSH) are essential for the cellular detoxification of reactive oxygen species in brain cells. A compromised GSH system in the brain has been connected with the oxidative stress (Dringen et al., 2003). As an antioxidant, GSH metabolizes ROS and peroxides primarily by serving as a cofactor for GSH-dependent enzymes such as GSH peroxidase. In addition, antioxidants such as the lipophilic free radical scavenger $\alpha$-tocopherol (vitamin E), or the hydrophilic compound ascorbate (vitamin C), the two most prominent antioxidants of their class, can directly interact with ROS at the molecular level (Finkel et al., 2000, Halliwell 1996, Sies 1993). Studies in perfused rat liver (Valls et al., 1994) and isolated rat hepatocytes (Beyer ef al., 1996) have shown that exogenously added $\mathrm{CoQ}_{10}$ can act as an antioxidant.

\subsection{1. $\mathrm{COQ}_{10}$}

$\mathrm{CoQ}_{10}$ or ubiquinone $(2,3$ di methoxy-5methyl 6 multi-prenyl-1, 4, benzoquinone) exerts its main natural function in mitochondria as a part of the 
electron transport chain, but is also present in low concentrations in plasma and in cell membranes where it functions as an antioxidant by preventing lipid peroxidation (Enster et al., 1995). It is a highly lipophilic compound which carries electrons from complex-1 and complex-ll to complex-III. CoQ $\mathrm{Q}_{10}$ can accept one electron and get converted to an intermediate semi-ubiquinone which then can accept one electron to get converted to its reduced form called ubiquinol (Figure 6). However, due to its insoluble nature, to study the mechanism by which $\operatorname{CoQ}_{10}$ offers protection is difficult. Recently, a water soluble formulation of $\mathrm{CoQ}_{10}$ was prepared by using a patented protocol, at the National Research Council, Ottawa, by Dr. Marianna Sikorska and Dr. Henryk Borowy-Borowski. The water soluble formulation is readily taken up by cells in culture thereby enabling further studies to exemplify its anti-oxidant capabilities.

\subsection{Cell lines}

It is difficult to study the biochemical mechanisms of neurodegenerative diseases due to the lack of availability of human neurons because neurons are post-mitotic tissues. Human teratocarcinoma (NT2N) and Human Neuroblastoma (SH-SY5Y) cells have been used as neuronal models to study neuronal functions.

\subsubsection{Human teratocarcinoma cells}

NT2 cells can be differentiated into neuronal phenotypes by exposing them with retinoic acid. Upon the exposure to RA, the use of differential adhesion matrices 
Figure 6. The different forms of $\mathrm{CoQ}_{10}$<smiles>CC/C(C)=C\CC1=C(C)C(=O)C(OC)=C(OC)C1=O</smiles><smiles></smiles><smiles>[R]c1c(C)c(O)c(OC)c(OC)c1O</smiles>

Oxidized $\mathrm{COQ}_{10}$ or ubiquinone can accept one electron and form an intermediate semiubiquinone radical. This radical can then accept one more electron to form the reduced form also known as ubiquinol. 
and mitotic inhibitors, the cells develop morphological and cytoskeletal characteristics of postmitotic central nervous system neurons. They resemble human primary neurons and like them, elaborate processes that differentiate into dendrites (Pleasure et al., 1992, Pleasure et al., 1993). Commitment of NT2 cells to a stable neuronal phenotype is irreversible.

\subsubsection{Human neuroblastoma cells (SH-SY5Y)}

SH-SY5Y cells can be differentiated into human neuron like cells by treating them with retinoic acid and are dependent on brain derived neurotrophic factor (BDNF). This treatment with RA and BDNF causes expression of neuron specific markers like neurofilaments and withdrawal from cell cycle differentiation (Encinas et al., 2000). Differentiation of neuroblasts occurs once they are arrested in the $G_{0}$ phase of the cell cycle (Encinas et al., 2000). Removal of BDNF makes the cells to re-enter $S$ phase, leading to apoptosis due to unscheduled entry into the S phase (Encinas et al., 2000). 


\section{Objectives}

1. To differentiate NT2 and SH-SY5Y cells into neuronal cells in order to use them as a model to study oxidative stress induced neuronal cell death.

2. To investigate if direct oxidative stress causes apoptotic cell death.

3. To examine if water soluble $\mathrm{COQ}_{10}$ can offer neuroprotection against oxidative stress and prevent apoptosis.

4. To study the mechanism of neuroprotection by $\mathrm{CoQ}_{10}$ :

1. As an antioxidant

2. Restoring mitochondrial function.

5. To study the effect of environmental toxin: paraquat, an herbicide on neuronal cells and determine if water soluble $\mathrm{CoQ}_{10}$ can offer protection. 


\section{CHAPTER 2}

\section{MATERIALS AND METHODS}

\subsection{Chemical and supplies}

\subsubsection{Cell Lines}

Human Neuroblastoma (SH-SY5Y) cells were purchased from the American Type Culture Collection (ATCC), Manassas, VA, USA. The Human Teratocarcinoma (NT2) cells were purchased from Stratagene cloning systems, La Jolla, CA, USA.

\subsubsection{Media}

DMEM F12, L-Glutamine and Gentamycin were purchased from Gibco BRL, WWR, Mississauga, ON, Canada. Fetal bovine serum was purchased from Winsent Inc, Quebec, Canada. Matrigel matrix was purchased from BectonDickinson, CA, USA. Recombinant hBDNF was purchased from Almone Labs, Israel. Uridine, fluorodeoxyuridine, cytosine arabinoside, retinoic acid and collagen were purchased from Sigma Chemical Company, Mississauga, ON, Canada

\subsubsection{Coenzyme Q10}

Water-soluble $\mathrm{COQ}_{10}$ was formulated in the National Research Council (NRC), Ottawa, Canada by a patented protocol developed by Dr. Marianna Sikorska and Dr. Henryk Borowy-Borowski (US Patent No. 6,045, 826). 


\subsubsection{Other chemicals}

Most of the chemicals including ATP, BSA, CHAPS, DTT, DTNB, EDTA, EGTA, GSH, GSH Reductase, HEPES, hydrogen peroxide, HRP, luciferinluciferase, low melting point agarose, HEPES, MDA, $\mathrm{MgCl}_{2}, \mathrm{NADPH}, \mathrm{Na}_{2} \mathrm{EDTA}$, parahydroxyphenylaceticacid, paraquat, succinate, thiobarbituric acid, trichloroacetic acid and trypsin were purchased from Sigma Chemical Company, Mississauga, ON, C anada. Triton $\times-100$ was o btained from Gibco BRL, VWR, Mississauga, $\mathrm{ON}$, Canada. DMSO, $\mathrm{NaOH}, \mathrm{NaCl}, \mathrm{NaHCO}_{3}$ and sucrose were purchased from BDH Inc., Toronto, Canada. Glycine and agarose were purchased from EM Sciences, NJ, USA. DCFDA, DEVD-AMC Hoechst, LLVYAMC and mitotracker Red $\mathrm{CM}-\mathrm{H}_{2} \mathrm{XRos}$ were obtained from Molecular Probes, Eugene, OR, USA. Protein assay reagent was purchased from Bio Rad, Ontario, Canada.

\subsection{Apparatus and instrumentation}

Fluorescent and phase contrast pictures were taken using a fluorescent microscope (Leica DM IRB, Germany). Fluorescence measurements were conducted in multiwell plate reader with the help of Spectra Max Gemini XS (Molecular Devices, Sunnyvale, California). Absorbance was measured by a UVVisible Spectrophotometer (Agilent Technologies). Absorbances in 96 well microtiter plates were measured using a Bio-tek ELx 808ru Ultra Microplate Reader.

Cell culture was conducted under sterile conditions in the class-ll type A/B3 Biosafety cabinet (Nuaire), and all cultures were maintained in a $\mathrm{CO}_{2}$ 
incubator containing a HEPA filter (Thermo Forma). Centrifugation was done using low speed centrifuge (Jouan) and DESAGA (Sarstedt-Gruppe). Other general laboratory equipment used included the following:

A pH Meter (WWR, Model 8100) with buffer solutions from VWR, an Adventurer ${ }^{T M}$ balance (OHAUS), Vortex Jr. Mixer from Scientific Industries inc, 1296-002 DELFIA ${ }^{R}$ plate shaker from Wallac, a heat block (Gibco BRL, WWR, Canada) Rocking platform model 200 from WWR, a Corning stirrer from Fisher Scientific (Toronto, Ontario), a Dounce homogenizer from Kontes Glass Company (NJ, USA), freezer vials (WWR) and Eppendorf pipettes (Fisher Scientific).

\subsection{Cell Culture}

\subsubsection{Human Teratocarcinoma Cells}

Cells were grown and differentiated using a slight modification of the manufacturer's protocol. NT2 cells were grown in D-MEM/F-12 growth medium supplemented with 10\% (V/v) Fetal Bovine Serum (FBS), 2 mM L-glutamine and $20 \mu \mathrm{g} / \mathrm{mL}$ gentamycin at $37^{\circ} \mathrm{C}$ at $5 \% \mathrm{CO}_{2}$. The cells were sub cultured by splitting 1:5 twice a week. For differentiation, cells were seeded in a $25 \mathrm{~m}^{2}$ flask and treated with normal growth medium containing $10 \mu \mathrm{M}$ retinoic acid twice weekly for 5 weeks. The cells were then sub cultured $1: 3$ and replated in complete DMEM/F-12 media for one day. Next day, the cells were put in serum free media for 5 minutes and differentiated neuronal cells were mechanically dislodged by gently striking the flasks. Then the cells were replated in $60 \times 15 \mathrm{~mm}$ petri-plates, 
Which were pre-coated with Matrigel Matrix and maintained in normal growth media containing mitotic inhibitors ( $1 \mu \mathrm{M}$ cytosine arabinoside (araC), $10 \mu \mathrm{M}$ fluorodeoxyuridine (FrdU) and $10 \mu \mathrm{M}$ uridine (Urd)) for at least 3 weeks. Over the weeks, half of the medium was changed twice a week. Differentiated neurons (NT2N) were obtained 3-4 weeks after treatment with mitotic inhibitors. A mixed culture containing both neurons and astrocytes (NT2N/A) was obtained during some experiments.

\subsubsection{Human Neuroblastoma Cells}

SH-SY5Y cells were grown in Ham's F12 medium with $2 \mathrm{mM}$ L-glutamine that was modified to contain $1.5 \mathrm{~g} / \mathrm{L}$ sodium carbonate, $10 \%$ Fetal Bovine Serum and $10 \mu \mathrm{g} / \mathrm{mL}$ gentamycin at $37^{\circ} \mathrm{C}$ at $5 \% \mathrm{CO}_{2}$. Differentiation of these cells was carried out using a previously desribed method (Encinas et al., 2000). Cells were plated in $60 \times 15 \mathrm{~mm}$ petri-plates, which were pre-coated with $0.05 \%$ collagen. On the day after plating the cells, All-trans Retinoic acid was added to a final concentration of $10 \mu \mathrm{M}$ in $\mathrm{F} 12$ medium containing $15 \%$ Fetal Bovine Serum for 5 days. After 5 days in the presence of RA, the cells were washed twice with F12 medium and incubated with $50 \mathrm{ng} / \mathrm{mL}$ brain derived neurotrophic factor (BDNF) in Serum Free Media (F12 medium without FBS) for 7 days.

\subsection{Experimental treatments}

\subsubsection{Oxidative Stress}




\subsubsection{1. $\mathrm{H}_{2} \mathrm{O}_{2}$ Treatment}

Differentiated NT2N and SH-SY5Y cells were either pre-treated with $30 \mu \mathrm{g} / \mathrm{mL}$ Coenzyme $Q_{10}\left(\mathrm{CoQ}_{10}\right)$ for 24 hours prior to treatment or directly subjected to oxidative stress by incubation with $100 \mu \mathrm{M} \mathrm{H}_{2} \mathrm{O}_{2}$ for 1 hour at $37^{\circ} \mathrm{C}$. Then the media was replaced with fresh complete media without $\mathrm{H}_{2} \mathrm{O}_{2}$, with or without 30 $\mu \mathrm{g} / \mathrm{mL} \mathrm{CoQ} 10$ and experiments were carried out at various time intervals as indicated in the figures.

\subsubsection{Paraquat Treatment}

Differentiated SH-SY5Y cells were either pre-treated with $30 \mu \mathrm{g} / \mathrm{mL}$ water-soluble Coenzyme $Q_{10}\left(C o Q_{10}\right)$ for 24 hours or directly subjected to paraquat treatment by incubation with $100 \mu \mathrm{M}$ paraquat in complete media for 48 hours at $37^{\circ} \mathrm{C}$.

\subsection{Cellular Staining and Microscopy}

In order to study the morphology, NT2N and SH-SY5Y cells were grown, differentiated and treated as mentioned above. After 6 hours of treating both NT2 and SH-SY5Y cells with $\mathrm{H}_{2} \mathrm{O}_{2}$, and 48 hours of treating SH-SY5Y cells with paraquat, the cells were stained with Hoechst $33342(10 \mu \mathrm{M}$ final concentration) for 10 minutes. The media containing excess Hoechst dye was removed by aspiration and replaced with $2 \mathrm{~mL}$ of $1 X$ PBS. The cells were then examined under a fluorescent microscope, and phase contrast and fluorescence pictures were taken. These pictures were processed using Adobe Photoshop 7.0 software. 


\subsection{Comet Assay}

The comet assay was performed using a slight modification of a previously described method (Gajendran ef al., 2000). NT2N cells were treated with hydrogen peroxide and SH-SY5Y cells were treated with paraquat as mentioned above. After 3 hours (for $\mathrm{H}_{2} \mathrm{O}_{2}$ ) and 48 hours (for paraquat) of treatment respectively, the cells were incubated with $0.1 \%$ trypsin for about 5 minutes. The cells were harvested by mechanical dislodging. $10 \mu \mathrm{L}$ of cells (about 10,000 cells) from the control and treated samples were mixed with $80 \mu \mathrm{L}$ of warm lowmelting point agarose (LMP) $\left(0.75 \%, 37^{\circ} \mathrm{C}\right)$ in a microfuge tube and spread on a glass slide pre-coated with $200 \mu \mathrm{L}$ of $0.1 \%$ agarose in such a way that half of the gel was on the coarse surface and the other half on the smooth, iransparent surface (agarose gel tends to slide away from the smooth surface during processing). The slides were incubated at $4^{\circ} \mathrm{C}$ for about 15 minutes. Slides were then immersed immediately in a tray containing a freshly prepared cold lysis buffer (2.5 mM NaCl, $100 \mathrm{mM}$ EDTA, $10 \mathrm{mM}$ Tris, pH 10, $1 \%$ Triton $\times-100$ and 10\% DMSO). The sides were incubated in the dark for 1 hour at $4^{\circ} \mathrm{C}$. Slides were then washed in freshly prepared alkaline electrophoresis buffer $10.3 \mathrm{M}$ $\mathrm{NaOH}, 1 \mathrm{mM} \mathrm{Na}{ }_{2}$ EDTA, pH>13). The DNA was electrophoresed at $300 \mathrm{~mA}$ $(0.8 \mathrm{~V} / \mathrm{cm})$, washed wice in a neutralizing buffer $(0.4 \mathrm{M}$ Tris, $\mathrm{pH} 7.5)$ and stained with Hoechst $33342(10 \mu \mathrm{M})$. The cells were photographed under a fluorescent microscope (Zeiss, Axiovert 200), and phase contrast and fluorescence pictures Were processed using Adobe Photoshop 7.0 software. 


\subsection{Total Cell Lysate}

The cells w ere harvested by mechanical dislodging using a rubber policeman. Cells were then centrifuged at $500 \times \mathrm{xg}$ for 5 minutes. The supernatant was removed and the pellet was then washed twice with $1 X$ PBS pH 7.4 and centrifuged again at 500xg for 5 minutes. The supernatant was removed and the pellet was resuspended in $0.4 \mathrm{~mL}$ of extraction buffer ( $25 \mathrm{mM}$ HEPES pH 7.25, 5 $\mathrm{mM} \mathrm{MgCl} 2,1 \mathrm{mM}$ EGTA, $0.1 \%$ Triton $\times 100$ ). The re suspension in the buffer was transferred into a cell homogenizer. Cells were homogenized with 20 strokes to produce the total cell lysate.

\subsection{Protein Estimation}

The concentration of proteins present in the total cell lysate sample was estimated using the protocol from BioRad Laboratories. The protein estimation was carried out by taking $10 \mu \mathrm{L}$ aliquots of each total cell lysate sample, $790 \mu \mathrm{L}$ of water and $200 \mu \mathrm{L}$ of BioRad protein assay reagent to a total volume of $1 \mathrm{~mL}$ in plastic cuvettes. The mixtures were vortexed and allowed to stand for 10 minutes at room temperature. The absorbance was then taken using a UV-Visible Spectrophotometer and analyzed at $595 \mathrm{~nm}$. The standard curve was prepared by using various amounts of a standard protein solution and recording the absorbance in identical condition.

\subsection{Proteasome and Caspase-3 Activity}


Proteasome and caspase- 3 assays were performed using a previously published method (Naderi et al, 2003). Total NT2N and SH-SY5Ycell lysates were obtained as mentioned earlier. The proteasome assay was performed in a Sarstedt 96 well plate. $20 \mu \mathrm{L}$ of total cell lysate was incubated with $50 \mu \mathrm{L}$ LLVY-AMC fluorogenic peptide substrate in a $1 \times$ LLVYase buffer $(0.1 \mathrm{M}$ Tris- $\mathrm{HCl}, \mathrm{pH} 8.0,5 \mathrm{mM} \mathrm{MgCl}$ ) for 1 hour at $37^{\circ} \mathrm{C}$. The total volume of the reaction mixture was made to $100 \mu \mathrm{L}$ with distilled water. After incubation for 1 hour, fluorescence was measured at an excitation and emission wavelengths of $370 \mathrm{~nm}$ and $440 \mathrm{~nm}$ respectively, using the Spectra Max Gemini XS. For the caspase-3 assay, $20 \mu \mathrm{L}$ of total cell lysate was incubated with $200 \mu \mathrm{L}$ DEVD-AMC fluorogenic peptide substrate in a $1 \mathrm{X}$ DEVDase buffer (0.1 M HEPES, pH 7.4, 2 mM DTT, 0.1\% CHAPS, 1\% Sucrose) for 1 hour at $37^{\circ} \mathrm{C}$. After incubation for 1 hour, fluorescence was measured in a 96 well micro-titer plate at an excitation and emission wavelengths of $400 \mathrm{~nm}$ and $505 \mathrm{~nm}$ respectively, using the Spectra Max Gemini XS. The Caspase-3 and proteasome activity were expressed per microgram of protein. Protein concentration was measured using the Bio Rad protein assay reagent, and bovine serum albumin was used as a standard. Microsoft Excel version 6.0 software was used for data representation and statistical analysis.

\subsection{Reduced Glutathione (GSH) Measurements}

GSH assay was performed using a previously published method (Baker et al., 2003). NT2 cells were grown, differentiated and treated with $100 \mu \mathrm{M} \mathrm{H}_{2} \mathrm{O}_{2}$. GSH levels were measured in cells 24 hours after $\mathrm{H}_{2} \mathrm{O}_{2}$ treatment. The total cell 
extract was obtained as mentioned above. $50 \mu \mathrm{L}$ of the total cell lysate was incubated with 1000L of reaction mixture containing $1 \mathrm{mM} \mathrm{NADPH}, 100 \mathrm{mM}$ $\mathrm{Na}_{2} \mathrm{HPO}_{4}, 100$ units $\mathrm{GSH}$ reductase and $1 \mathrm{mM}$ DTNB for 5 minutes. The absorbance was measured at $412 \mathrm{~nm}$ in a 96 well micro-titer plate using Bio-tek ELx 808ru Ultra Micro plate Reader. GSH levels were measured by running internal standards of GSH. Results were expressed per microgram of protein. Protein concentration was measured using the Bio Rad protein assay reagent and bovine serum albumin was used as a standard as mentioned above. Microsoft Excel version 6.0 software was used for data representation and statistical analysis.

\subsection{Lipid Peroxidation Assay}

Lipid peroxidation was performed using a previously described method (Cereser et al., 2001). SH-SY5Y cells were grown, differentiated and treated for 24 hours with $\mathrm{H}_{2} \mathrm{O}_{2}$ as mentioned earlier. The total cell lysate was obtained as mentioned earlier and then centrifuged at $500 \times \mathrm{xg}$ for 5 minutes and the supernatant was removed. The pellets were re suspended in $0.25 \mathrm{~mL}$ of extraction buffer. $100 \mu \mathrm{L}$ of cell membrane sample was incubated with $1 \mathrm{ml}$ of thiobarbituric acid on a $100^{\circ} \mathrm{C}$ heatblock for 15 minutes. After cooling, absorbance at $535 \mathrm{~nm}$ was measured using a spectrophotometer. Lipid peroxidation levels were determined running internal standards of Malonaldehyde (MDA). Results were calculated per microgram of protein. Protein concentration was measured using the Bio Rad protein assay reagent with bovine serum albumin as a standard (mentioned 
earlier). Microsoft Excel 6.0 software was used for data representation and statistical analysis.

\subsection{Measurement of Total ROS}

Production of total ROS was measured after 6 hours and 24 hours of $\mathrm{H}_{2} \mathrm{O}_{2}$ treatment in NT2N cells, while total ROS production was monitored after 48 hours of paraquat treatment in SH-SY5Y cells. The membrane permeable dye 2', $7^{\prime}$ - dichlorofluorescein diacetate (DCFDA) was used to detect ROS production using a modification of a previously published procedure (Siraki et al., 2002). Briefly, at various time points after treatment, the cells were incubated with DCFDA to a final concentration of $10 \mu \mathrm{M}$ for 10 minutes at $37^{\circ} \mathrm{C}$. Cells were harvested by mechanical dislodging using a rubber policeman and centrifuged at $500 \times g$ for 5 minutes. The pellet was washed and re suspended in PBS, and fluorescence (excitation $500 \mathrm{~nm}$ and emission at $520 \mathrm{~nm}$ ) was measured using a Spectra Max Gemini XS multi-well plate fluorescence reader (Molecular Device, Sunnyvale, California). Protein concentration was measured using the Bio Rad protein assay reagent and results were shown per microgram of protein using bovine serum albumin as a standard. Microsoft Excel version 6.0 software was used for data representation and statistical analysis.

\subsection{Measurement of ROS Production from Isolated Mitochondria}

SH-SY5Y cells were grown, differentiated and treated for 24 hours with $\mathrm{H}_{2} \mathrm{O}_{2}$ as mentioned above and intact mitochondria were isolated using a previously 
published method (Li et al., 2003). Cells were harvested by mechanical dislodging using a rubber policeman and centrifuged at $500 \times \mathrm{xg}$ for 5 minutes. They were washed twice with ice cold PBS and centrifuged at $250 \times 9$, the cells were re suspended in isolation buffer containing $1 \mathrm{mM}$ EDTA, $10 \mathrm{mM}$ HEPES $(\mathrm{pH} 7.4)$ and $250 \mathrm{mM}$ sucrose. Cells were homogenized by a Dounce homogenizer with 20 strokes. The disrupted cells were centrifuged for 5 minutes at $600 \times \mathrm{g}$ at $4^{\circ} \mathrm{C}$. The supernatant was collected and centrifuged at $15,000 \times \mathrm{g}$ at $4^{\circ} \mathrm{C}$ for 5 minutes and the resulting pellet was mitochondria. The pellet was resuspended in buffer without EDTA. Mitochondrial suspensions were kept on ice and all the experiments were performed within 5 hours.

Mitochondrial hydrogen peroxide was measured u sing $p$-hydroxy phenyl acetic acid (PHPA) by an increase in the fluorescence due to oxidized pm hydroxyphenylacetate fluorescence by horseradish peroxidase as previously described (Li et al., 2003). $0.25 \mathrm{mg}$ of mitochondrial suspension was added to a $100 \mu l$ reaction mixture containing $0.25 \mathrm{M}$ Sucrose, $1 \mathrm{mM} \mathrm{MgCl} 2,10 \mathrm{mM}$ HEPES $0.5 \mathrm{mg} / \mathrm{mL}$ PHPA and 0.4 units of HRP per well. $100 \mathrm{mM}$ succinate was added and the contents were mixed. After 30 minutes of incubation, the fluorescence of oxidized PHPA (excitation $320 \mathrm{~nm}$, emission $400 \mathrm{~nm}$ ) was measured in a 96 well micro-titer plate using the Spectra Max Gemini XS. Mitochondrial hydrogen peroxide production was determined by interpolation from the standard curve generated by reagent hydrogen peroxide. Total mitochondrial protein was estimated using BioRad with bovine serum albumin as a standard and the results 
were expressed per microgram of protein. Microsoft Excel version 6.0 software was used for data representation and statistical analysis.

\subsection{Mitochondrial Membrane Potential}

NT2 and SH-SY5Y cells were grown and treated with $\mathrm{H}_{2} \mathrm{O}_{2}$ as mentioned above. Mitochondrial membrane potential was measured using Mitotracker $\mathrm{CM}-\mathrm{XH}_{2}-\mathrm{Ros}$ dye. The cells were treated with $0.5 \mu \mathrm{M}$ of the dye and incubated for 15 minutes. Media containing the dye was removed and replaced by $3 \mathrm{~mL}$ 1X. PBS. The cells were observed under a fluorescent microscope, and phase contrast and fluorescence pictures were processed using Adobe Photoshop 7.0 software.

\subsection{ATP Determination}

ATP was measured from isolated mitochondria. SH-SY5Y cells were grown and treated as mentioned above and intact mitochondria were isolated as mentioned previously ( $L i$ et al., 2003). Isolated mitochondria were re-suspended in a reaction mixture containing $0.25 \mathrm{M}$ sucrose, $1 \mathrm{mM} \mathrm{MgCl}, 10 \mathrm{mM} \mathrm{HEPES}$ and 1 mM EDTA. This suspension was briefly sonicated and centrifuged at $5000 \times \mathrm{g}$ for 5 minutes. $100 \mu \mathrm{L}$ of this supernatant was incubated with $100 \mu \mathrm{L}$ luciferinluciferase ( $5 \mathrm{mg} / \mathrm{mL}$ ) and bioluminescence was measured using the Spectra Max Gemini XS. Mitochondrial ATP levels were determined by running internal standards. Total mitochondrial protein was estimated using Bio Rad method with bovine serum albumin as a standard and the results were expressed as ATP amount per microgram of protein. Microsoft Excel version 6.0 software was used for data representation and statistical analysis. 


\section{CHAPTER 3}

RESULTS

\subsubsection{Differentiation of NT2 and SH-SY5Y Cells}

Human Teratocarcinoma cells and Human Neuroblastoma cells were used to study oxidative stress caused by hydrogen peroxide treatment. Previous studies have revealed that upon differentiation these cells behave similar to the neurons of the Central Nervous System (CNS) (Sandhu et al., 2003, Guillemain et al., 2000). Undifferentiated NT2 cells (Figure 7A) were treated with retinoic acid (RA) for 5 weeks. Cells appeared to form a dense, multilayer culture in which it is impossible to visualize any structure using phase-contrast microscopy (Figure 7B). After evenly replating the cells in media containing mitotic inhibitors, the cells came together to form cellular aggregates within 2 weeks. Moreover an extensive network of neurites developed and eventually formed clusters, which were connected to one another by large bundles of processes (Figure 7C).

Undifferentiated SH-SY5Y cells (Figure 7D) were treated with RA for 5 days during which some cells differentiated to a more neuronal phenotype by extending neuritic processes. Then the cells were incubated with hBDNF for 5 days. After the first day, some cells displayed neuritic processes and eventually formed aggregates (Figure 7E).

\subsubsection{Oxidative Stress Caused by Hydrogen Peroxide Induces Apoptosis in Differentiated Neuronal Cells \\ Cells were grown and differentiated as described in Materials and Methods. The differentiated neuronal cells were exposed briefly to $100 \mu \mathrm{M} \mathrm{H}_{2} \mathrm{O}_{2}$ (1 hour) in complete media, and then they were washed and incubated at $37^{\circ} \mathrm{C}$ in complete}


Figure 7. Morphology of NT2 cells during differentiation

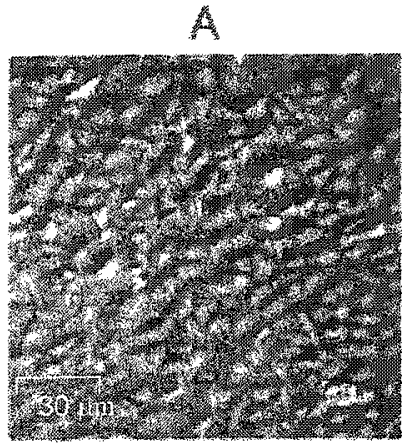

Undifferentiated

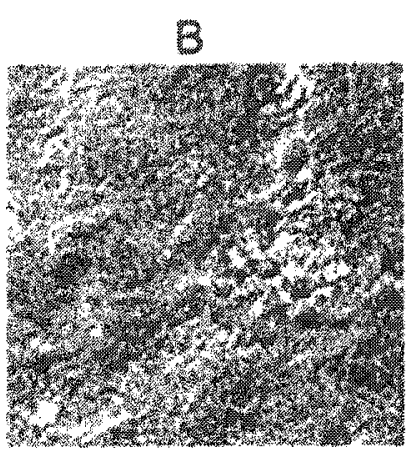

RA treatment

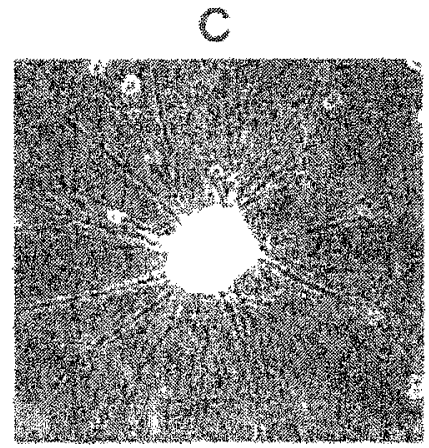

Mitotic inhibitors

Undifferentiated NT2 cells (A) were treated with Retinoic acid (RA) for 5 weeks in order to introduce differentiation. After 5 weeks the cells were incubated with media containing mitotic inhibitors for about 3 weeks. Phase contrast pictures were taken at the end of RA treatment (B) and after 3 weeks of incubation with mitotic inhibitors (C) at $400 X$ using a Leica DM IRB microscope. 
Figure 7. Morphology of SH-SY5Y cells during differentiation

$\mathrm{b}$

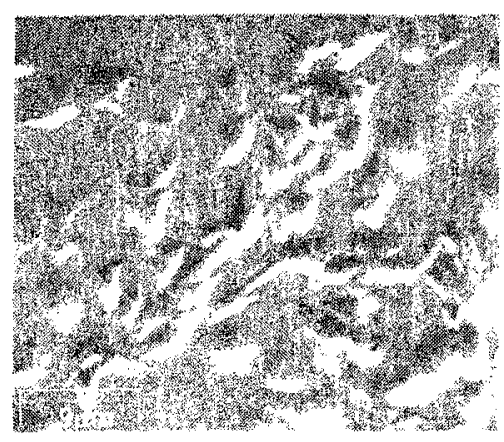

Undifferentiated
$\mathbf{E}$

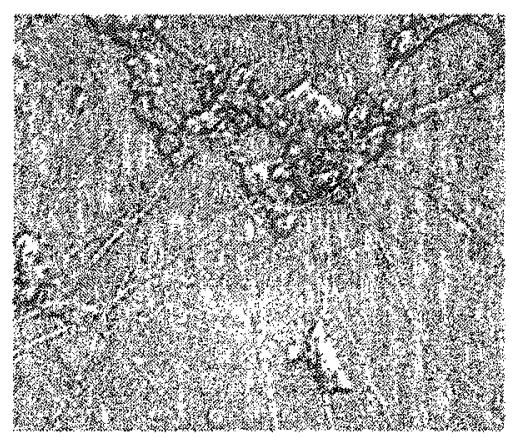

After RA and BDNF

Undifferentiated SH-SYSY cells (D) were treated with RA for 5 days and with BDNF for 7 days. After 7 days of hBDNF treatment $(E)$, phase contrast pictures were taken at $400 \mathrm{X}$ using a Leica DM IRB microscope. 
media. Various characteristics including cellular morphology and biochemical changes were monitored at various time intervals. Results (Figure 8B) indicated changes in morphology such as beading in the neuronal processes 6 hours after hydrogen peroxide treatment. The neurites appeared weakened, and the cells eventually lifted off from the substratum 24 hours a fter treatment (Figure 8 E). Figures 8 A \& 80 s how the morphology of differentiated neuronal cells without $\mathrm{H}_{2} \mathrm{O}_{2}$ treatment.

Nuclear condensation and DNA fragmentation are major characteristic features of apoptosis. Control and treated neuronal cells were stained with cellpermeable Hoechst dye to assess the nuclear morphology. The results shown in figure 9B \& 9E showed nuclear condensation in treated cells (Figure 9A \& 9D represents the control cells), indicating that oxidative stress induced by $\mathrm{H}_{2} \mathrm{O}_{2}$ treatment caused apoptosis in the neuronal cells. When the numbers of apoptotic nuclei were counted for the treated and untreated cells, an increase of about $35 \%$ (in the case of NT2N cells) and $25 \%$ (in the case of SH-SY5Y cells) was observed after treatment when compared to control (Figure 10). in order to assess the DNA degradation during apoptosis of neurons following oxidative stress, a comet assay was performed on the treated and control NT2N cells. The cells treated with hydrogen peroxide showed comet images indicating DNA damage (Figure 11B), while the control cells did not show a ny comet images (Figure 11A). These results indicated that the differentiated neuronal cells undergo apoptosis displaying all the characteristic apoptotic features following hydrogen peroxide treatment. 
Figure 8. Morphology of NT2N cell clusters following hydrogen peroxide treatment

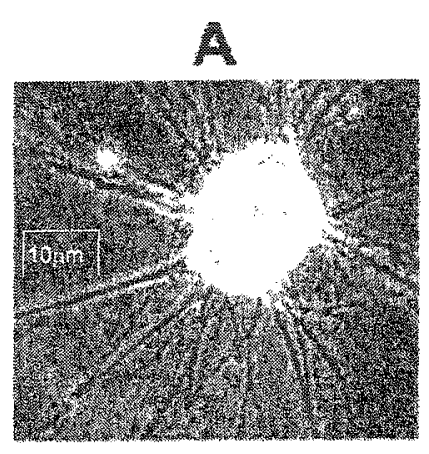

Control
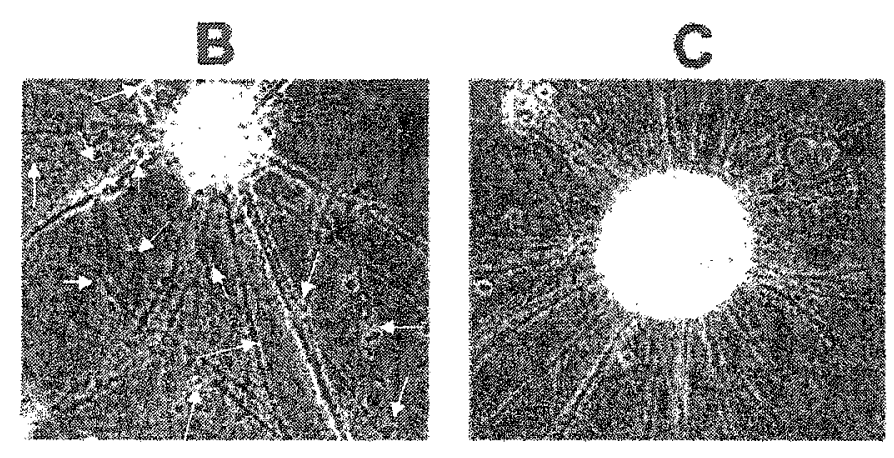

$\mathrm{H}_{2} \mathrm{O}_{2}-\mathrm{CoQ}_{10}$
$\mathrm{II}_{2} \mathrm{O}_{2}+\mathrm{COQ}_{10}$

Differentiated NT2 were treated with $100 \mu \mathrm{M}$ hydrogen peroxide in presence (C) and absence (B) of $\mathrm{CoQ}_{10}$ as described in the Materials and Methods. Figure $\mathrm{A}$ represents control cells which were not treated with hydrogen peroxide. After 6 hours of treatment, phase contrast pictures of NT2N were taken at magnifications of $400 \mathrm{X}$, using a Leica DM IRB microscope. Arrows in $\mathrm{B}$ indicate beading in the neuronal processes. 
Figure 8. Morphology of SH-SY5Y cells following hydrogen peroxide treatment

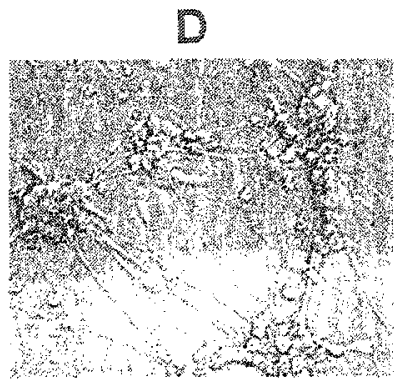

Control

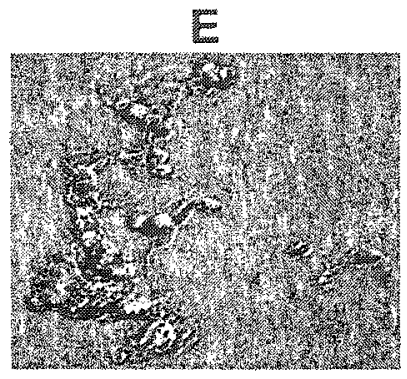

$\mathrm{H}_{2} \mathrm{O}_{2}-\mathrm{CoQ}_{10}$

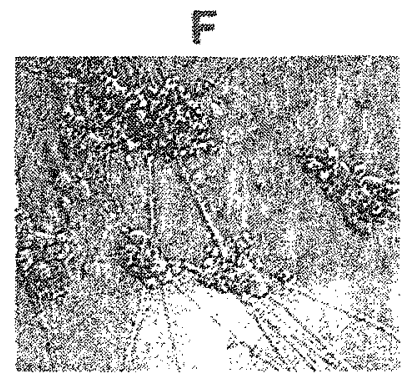

$\mathrm{H}_{2} \mathrm{O}_{2}+\mathrm{CoQ}_{10}$

Differentiated SH-SY5Y cells were treated with $100 \mu \mathrm{M}$ hydrogen peroxide in presence $(F)$ and absence $(E)$ of $\mathrm{CoQ}_{10}$ as described in the Materials and Methods section. Figure D represents control neuronal cells which were not treated with hydrogen peroxide. Phase contrast pictures for SH-SY5Y cells were taken 24 hours after treatment at a magnification of $400 x$. 
Figure 9. Nuclear morphology of NT2N cells after hydrogen peroxide treatment

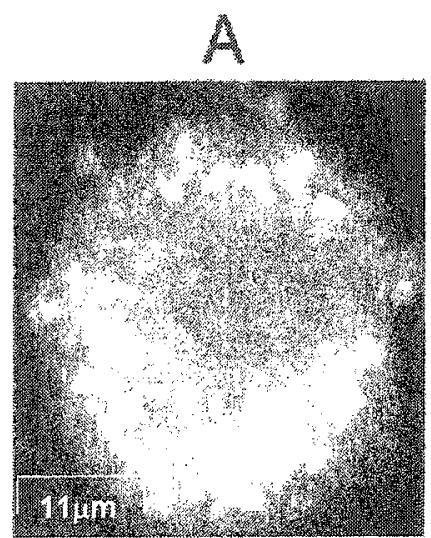

Control

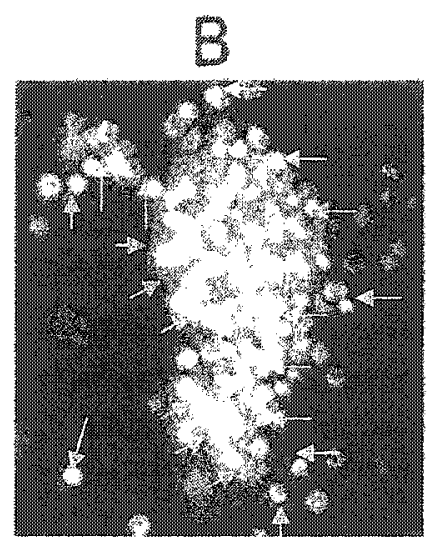

$\mathrm{H}_{2} \mathrm{O}_{2}-\mathrm{COQ} \mathrm{ro}$

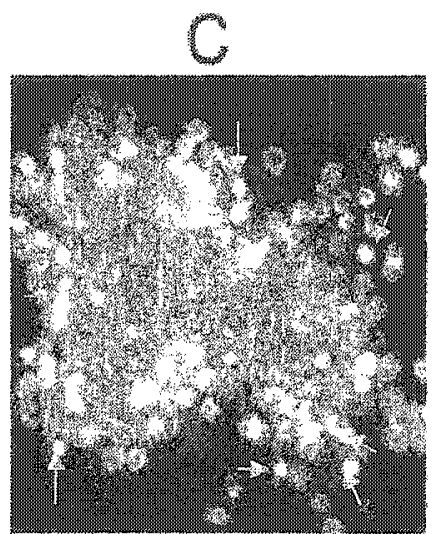

$\mathrm{H}_{2} \mathrm{O}_{2}+\mathrm{CoQ} 10$

After treating NT2N cells for 6 hours with hydrogen peroxide in the presence and absence of $\mathrm{COQ}_{10}$, Hoechst 33342 dye was added to the cells to study nuclear morphology. Nuclear condensation is clearly observed in cells treated with $\mathrm{H}_{2} \mathrm{O}_{2}$, in the absence of $\mathrm{COQ}_{10}$. The arrows indicate bright, condensed and rounded nuclei (B). Fluorescent pictures were taken at magnification of $400 \mathrm{X}$ using Leica DM IRB microscope. Figure $\mathrm{C}$ indicates cells treated with $\mathrm{H}_{2} \mathrm{O}_{2}$ in the presence of $\mathrm{CoQ}_{10}$, while figure $\mathrm{A}$ represents control cells. 
Figure 9. Nuclear morphology of SH-SY5Y cells after hydrogen peroxide treatment
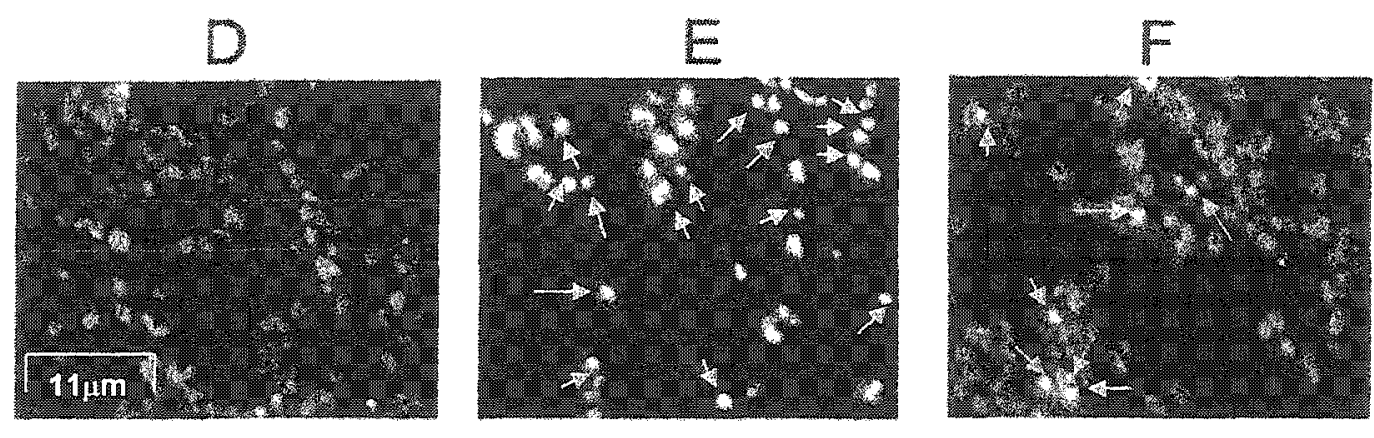

Control

$\mathrm{H}_{2} \mathrm{O}_{2}-\mathrm{CoQ}$

$\mathrm{H}_{2} \mathrm{O}_{2}+\mathrm{COQ}$

After treating SH-SY5Y cells for 24 hours, Hoechst 33342 dye was added to the cells to study nuclear morphology. Nuclear condensation is clearly observed in cells treated with $\mathrm{H}_{2} \mathrm{O}_{2}$, in the absence of $\mathrm{CoQ}_{10}$. Arrows indicate bright, condensed and rounded nuclei (E). Fluorescent pictures were taken at magnification of $400 X$ using Leica DM IRB microscope. Cells that were pretreated with $\mathrm{COQ}_{10}$ prior to $\mathrm{H}_{2} \mathrm{O}_{2}$ treatment are represented in figure $\mathrm{F}$. Figure $D$ represents control cells which were not treated with hydrogen peroxide. 
Figure 10. $60 Q_{10}$ rescues cells from undergoing apoptosis after hydrogen peroxide treatment

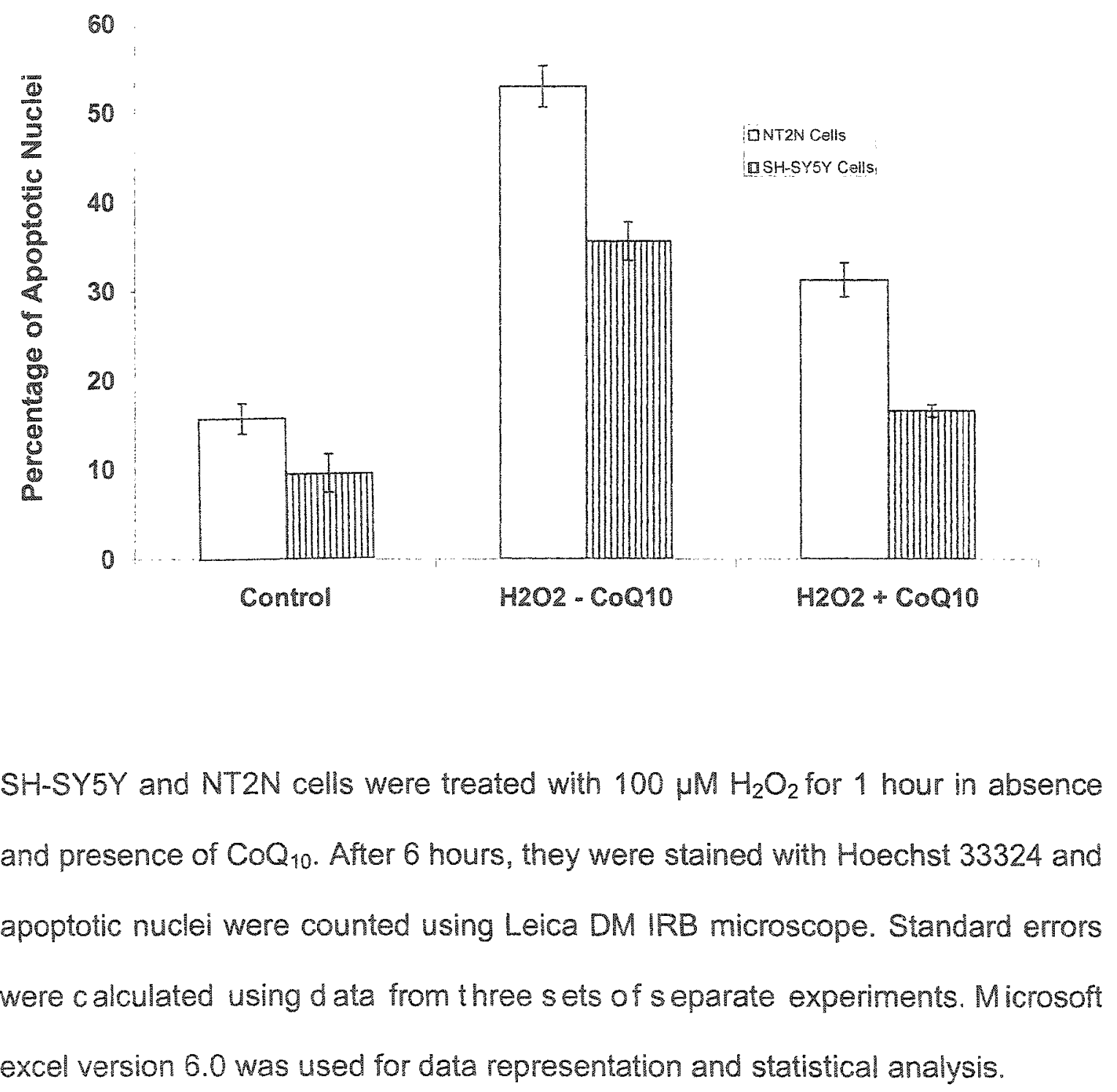


Figure 11. DNA fragmentation during apoptosis induced by hydrogen peroxide treatment

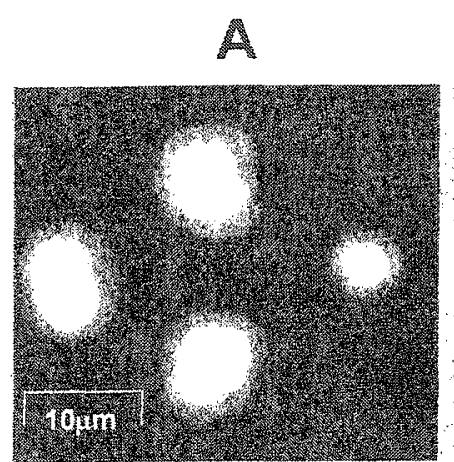

Control

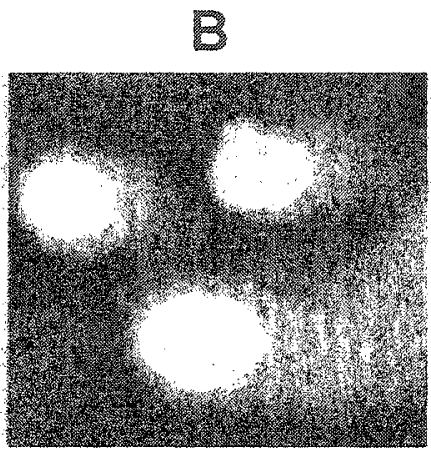

$\mathrm{H}_{2} \mathrm{O}_{2}-\mathrm{CoQ}_{10}$

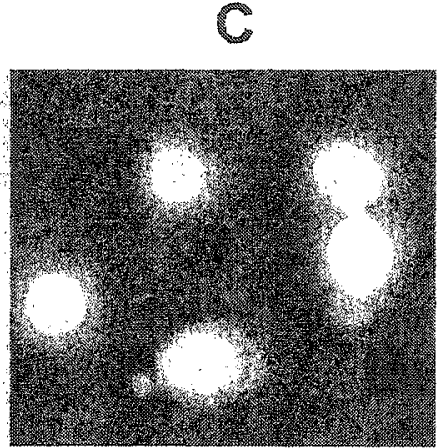

$\mathrm{H}_{2} \mathrm{O}_{2}+\mathrm{CoQ}_{10}$

Differentiated NT2 cells were treated with $100 \mu \mathrm{M} \mathrm{H}{ }_{2} \mathrm{O}_{2}$ in the absence (B) and presence (C) of $\mathrm{CoQ}_{10}$. A comet assay was conducted 3 hours after treatment. Figure A represents the control cells. Pictures of cells were taken under fluorescent light after staining with Hoechst 33342 dye, at a magnification of 400 $X$, using a Leica DM IRB microscope. DNA degradation is shown by comet-like images. 


\subsubsection{Generation of ROS by NT2N Cells following Oxidative Stress}

Several studies have shown that $\mathrm{H}_{2} \mathrm{O}_{2}$ treatment causes oxidative stress (Chang et al., 2003, Ratan et al., 1994, Enokido et al., 1990). In order to determine whether the brief exposure to $\mathrm{H}_{2} \mathrm{O}_{2}$ caused oxidative stress on Human Teratocarcinoma (NT2N) cells, the production of reactive oxygen species was monitored during the early and late phases of apoptosis using a redox sensitive dye 2', 7'- dichlorofluorescein diacetate (DCFDA). Results shown in figure 4 indicated a considerable increase in generation of ROS at intervals of 6 hours and 24 hours after hydrogen peroxide treatment. This indicated that $\mathrm{H}_{2} \mathrm{O}_{2}$ treatment led to oxidative stress in differentiated neuronal cells (Figure $12 \mathrm{~A} \&$ 12B).

\subsubsection{Neuroprotective Effect of Water Soluble Coenzyme $\mathbf{Q}_{10}$ on Neuronal Cells after Hydrogen Peroxide Treatment.}

$\mathrm{CoQ}_{10}$ is not only an important component of the mitochondrial electron transport chain but is also a potent anti-oxidant. To evaluate its role in protection against oxidative stress induced by hydrogen peroxide, a water-soluble formulation containing both oxidized and reduced forms of CoQ $\mathrm{Q}_{10}$ was used (Borowy-Borowski H, US Patent No. 6,045, 826). Cells were pre-treated with $\mathrm{CoQ}_{10} 24$ hours prior to inducing oxidative stress by hydrogen peroxide treatment as described in materials and methods. We observed that $\mathrm{CoQ}_{10}$ pre-treated cells were resistant to apoptosis following treatment. The percentage of apoptotic nuclei were less in the presence of $\mathrm{CoQ}_{10}$ (Figure 9C \& 9F) as compared to 
Figure 12.A. Production of total reactive oxygen species in NT2N cells after hydrogen peroxide treatment
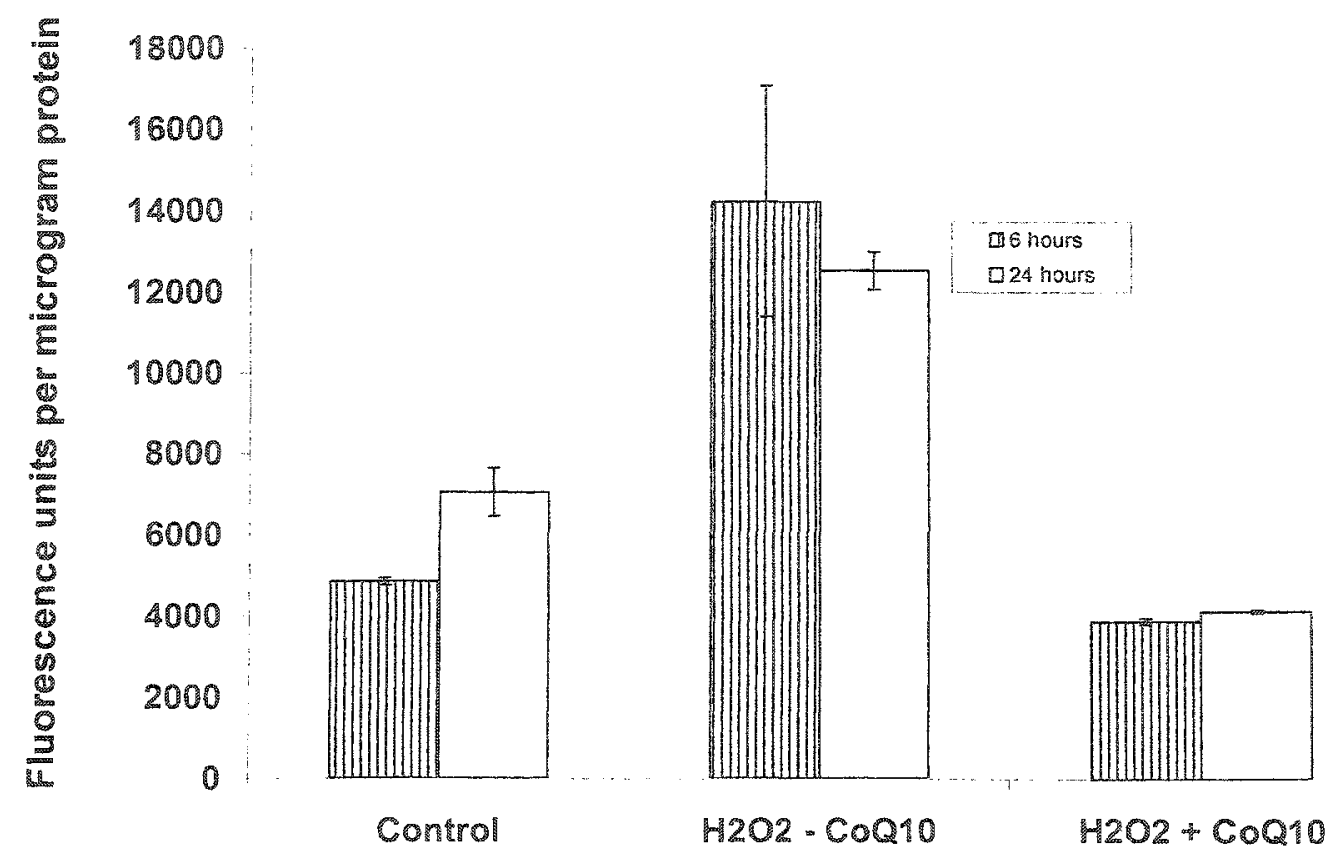

NT2N cells were treated with $100 \mu \mathrm{M} \mathrm{H}_{2} \mathrm{O}_{2}$ for 1 hour in absence or presence of $\mathrm{COQ}_{10}$, after which cells were washed with fresh media and incubated at $37^{\circ} \mathrm{C}$. ROS was measured following 6 hours and 24 hours of treatment using $2^{\prime}, 7^{\prime}$ dihydrofluorescein diacetate (DCFDA) Microsoft excel version 6.0 software was used to represent data and calculate standard deviation. Standard errors were calculated using data from three sets of separate experiments. 
Figure 12.B. Production of total reactive oxygen species in differentiated SH-SYSY cells after hydrogen peroxide treatment.

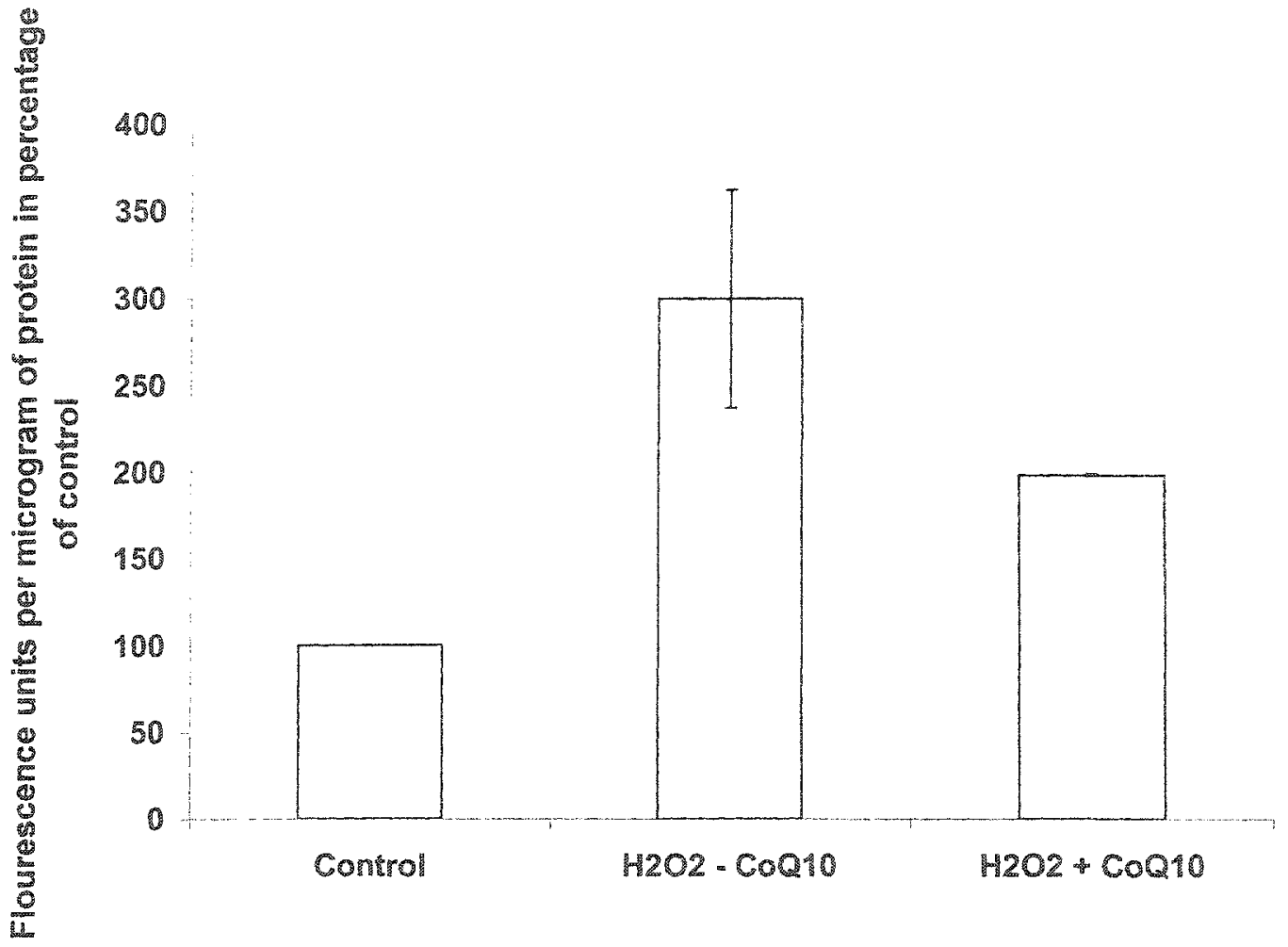

SH-SY5Y cells were treated with $100 \mu \mathrm{M} \mathrm{H}_{2} \mathrm{O}_{2}$ for 1 hour in absence or presence of $\mathrm{COQ}_{10}$, after which cells were washed with fresh media and incubated at $37^{\circ} \mathrm{C}$. ROS was measured following 24 hours of treatment using $2,7^{\prime}$ dihydrofluorescein diacetate (DCFDA) Microsoft excel version 6.0 software was used to represent data and calculate standard deviation. Standard errors were calculated using data from three sets of separate 
those treated in the absence of $\mathrm{COQ}_{10}$ (Figure 9B, 9E). The cells appeared to have healthier neuronal processes as compared to the cells treated with peroxide in the absence of $\mathrm{CoQ}_{10}$, and apoptotic features like nuclear condensation and DNA fragmentation were considerably inhibited in $\mathrm{COQ}_{10}$ pretreated cells (Figure 8C \& 8F) and the neuronal processes showed less beading. The percentage of celis undergoing apoptosis after hydrogen peroxide treatment was significantly reduced in $C o Q_{10}$ pre-treated cells (Figure 10). Similarly, DNA degradation was inhibited by $\mathrm{COQ}_{10}$ pre-treatment (Figure $11 \mathrm{C}$ ).

In order to determine whether or not $C O Q_{10}$ reduced the amount of $R O S$ generated, NT2N cells were treated as mentioned earlier, and ROS levels were monitored 6 hours and 24 hours after treatment. Results indicated that $\mathrm{CoQ}_{10}$ pre-treatment was able to bring down the level of ROS at all time points after treatment. (Figure 12A). Similar results were seen when ROS measurements were made after SHSY-5Y cells were treated for 24 hours (Figure $12 \mathrm{~B}$ ).

\subsubsection{Oxidative Stress Causes an Increase in Lipid Peroxidation which is decreased in the Presence of $\mathrm{COQ}_{10}$.}

An increase in lipid peroxidation production is a characteristic feature of cellular oxidative stress. Malonaldehyde (MDA), a bi-product of lipid peroxidation (LPO), is involved in DNA adduct formations, which can be responsible for carcinogenesis (Ray et al., 2002).

In order to determine whether $\mathrm{H}_{2} \mathrm{O}_{2}$ treatment increased lipid peroxidation in SH-SY5Y cells, a lipid peroxidation assay was conducted. Levels of MDA were 
assessed in order to study lipid peroxidation. After 24 hours of $\mathrm{H}_{2} \mathrm{O}_{2}$ treatment, cells showed a considerable increase in lipid peroxidation production compared to control cells or cells pre-treated with $\mathrm{COQ}_{10}$ (Figure 13). These results demonstrate that treatment with $\mathrm{H}_{2} \mathrm{O}_{2}$ induced oxidative stress on SH-SY5Y cells, resulting in an increased measurement of lipid peroxidation which was inhibited by $\mathrm{COQ}_{10}$.

\subsection{6. $C O Q_{10}$ Pre-treatment Results in Maintaining GSH Levels following Oxidative Stress}

Reduced GSH has an anti-oxidative effect against oxidative stress. In cells under oxidative stress, reduced glutathione (GSH) levels are decreased. In order to determine if $\mathrm{GSH}$ levels change following $\mathrm{H}_{2} \mathrm{O}_{2}$ stress. NT2N cells were treated with $\mathrm{H}_{2} \mathrm{O}_{2}$ in the presence and absence of $\mathrm{CoQ}_{10}$. After 24 hours of treatment, the GSH levels were monitored by using DTNB as described in Materials and Methods. Results indicated a decrease in the GSH levels after oxidative stress. However, in the cells pre-treated with $\mathrm{CoQ}_{10}$, the cellular levels of GSH were higher (Figure 14). These results show that $\mathrm{CoQ}_{10}$ pre-treatment helped cells maintain the GSH levels during oxidative stress. 
Figure 13. Lipid peroxidation in differentiated SH-SY5Y cells after hydrogen peroxide treatment

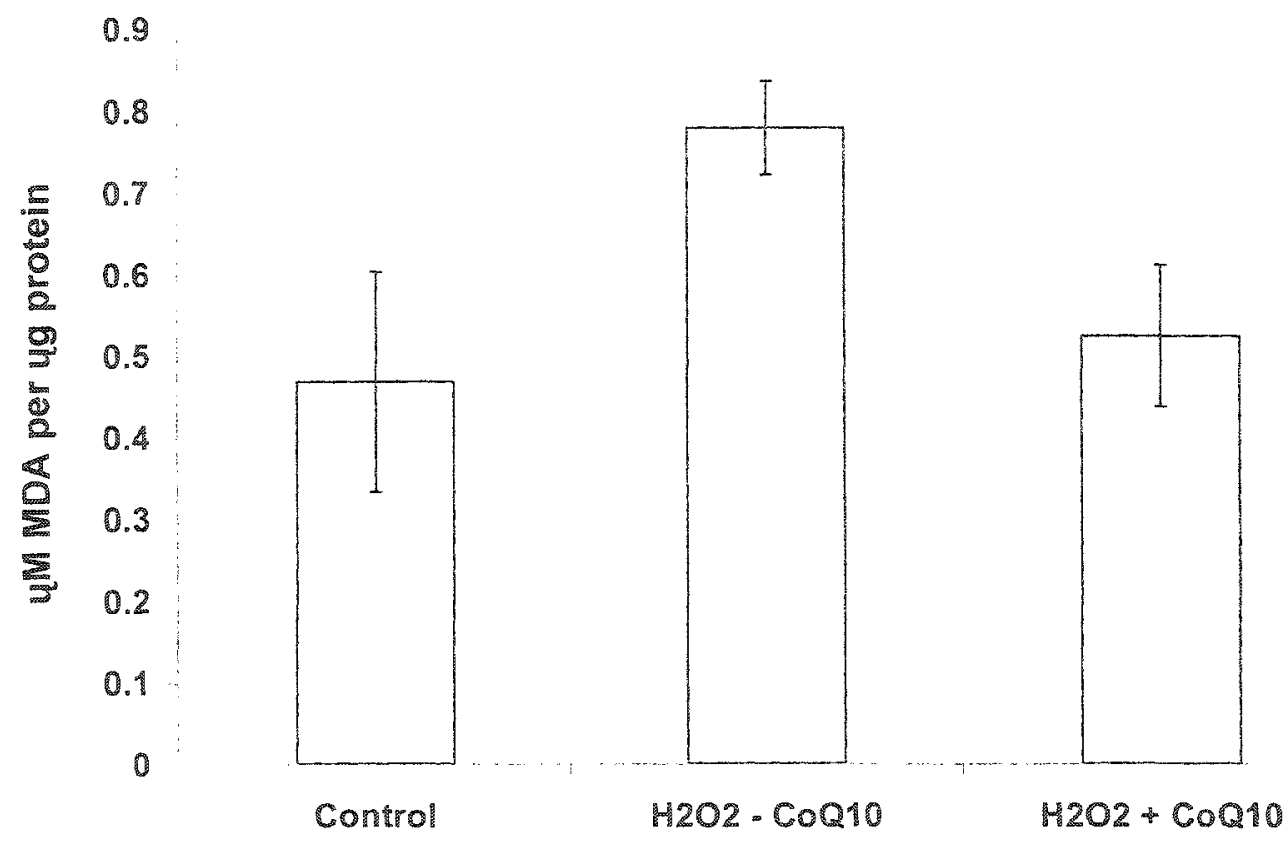

Differentiated SHSY-5Y cells were exposed to 24 hours of $\mathrm{H}_{2} \mathrm{O}_{2}$ treatment in the presence and absence of $\mathrm{CoQ}_{10}$, followed by a lipid peroxidation assay. Malonaldehyde was measured using thiobarbituric acid as mentioned in Materials and Methods. Microsoft Excel Version 6.0 software was used to represent data and calculate standard deviation. Results were calculated using internal standards of Malonaldehyde and expressed per microgram of protein. Standard errors were calculated using data from three separate sets of experiments. 
Figure 14. GSH levels in NT2N cells after hydrogen peroxide treatment

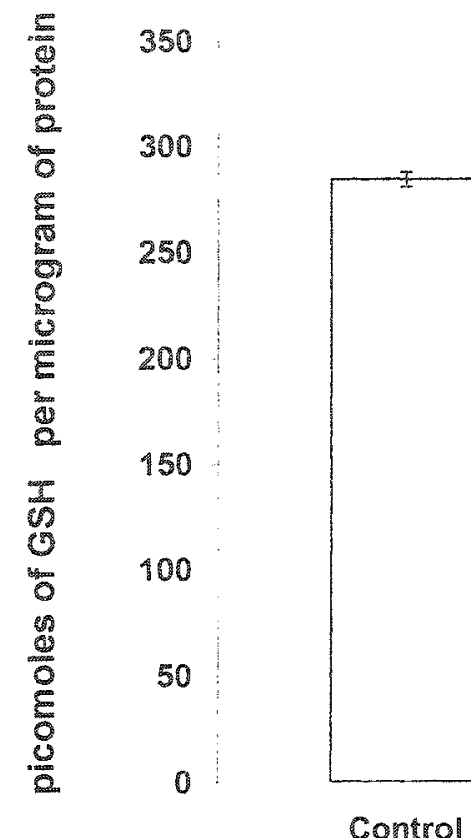

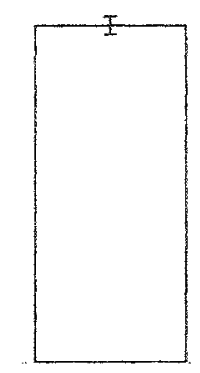

$\mathrm{H} 2 \mathrm{O} 2$ - $\mathrm{COQ} 10$

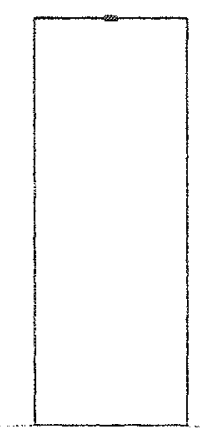

$\mathrm{H} 2 \mathrm{O} 2+\mathrm{COQ} 10$

After 24 hours of $\mathrm{H}_{2} \mathrm{O}_{2}$ treatment, NT2N cells were subjected to a GSH assay as mentioned in Materials and Methods. Microsoft Excel Version 6.0 software was used to represent data and calculate standard deviation. Results were calculated per microgram of protein and standard errors were calculated using data from three separate sets of experiments. $(p<0.05)$ 


\subsubsection{CoQ10 reduces the activity of caspase-3 and proteasome}

Proteases play a very essential role in apoptotic cell death. They are activated during apoptosis in many systems. Caspase-3 is a cysteine protease, generally thought to be involved in the execution phase of apoptosis. Similarly, proteasome proteases have also shown to be involved in apoptosis. We investigated if these proteases are activated in the cells challenged with oxidative stress.

Caspase- 3 activity was measured 24 hours after treating NT2N cells with $\mathrm{H}_{2} \mathrm{O}_{2}$. There was a significant increase in caspase- 3 activity following oxidative stress as compared to the control. Cells pre-treated with $\mathrm{CoQ}_{10}$ showed lowered caspase- 3 activity as compared to oxidatively stressed cells that were not pretreated with $\mathrm{COQ}_{10}$ (Figure 15A). Proteasome activation was observed 24 hours after oxidative stress was induced in NT2N cells (Figure 15B). The results indicated an increase in activity of proteases upon hydrogen peroxide treatment, in the absence of $\mathrm{CoQ}_{10}$. But $\mathrm{CoQ}_{10}$ pre-treatment reduced the proteasome activity after oxidative stress.

\subsubsection{Oxidative stress causes mitochondrial dysfunction and increased hydrogen peroxide generation from mitochondria; inhibition by Coenzyme Q}

Mitochondrial dysfunction leads to the increase in the production of ROS. To investigate whether hydrogen peroxide treatment caused mitochondrial dysfunction, we monitored the production of ROS from the mitochondria. It has 
Figure 15. A. Caspase-3 activity following hydrogen peroxide treatment

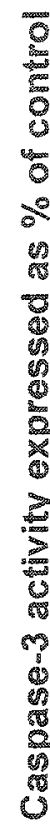

600

500

400

200

(1)

100

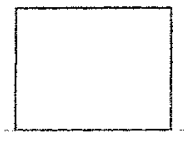

Control
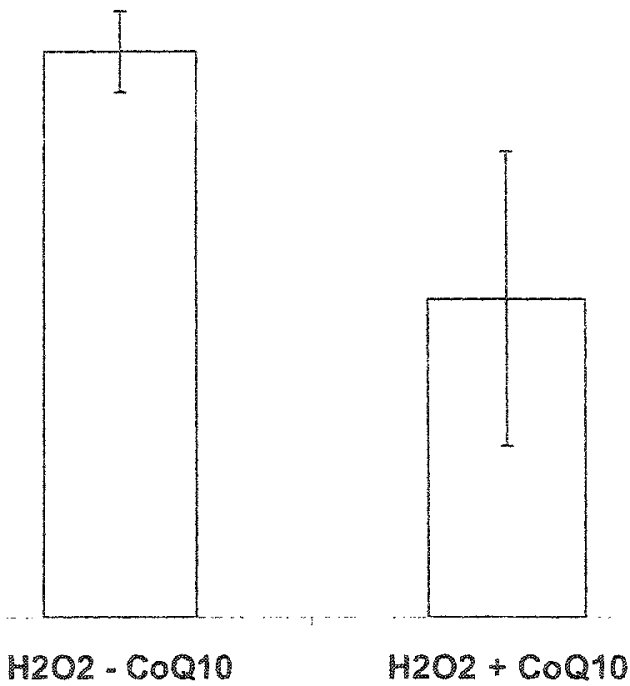

Caspase-3 assay was performed employing cell extracts from control and treated NT2N cells 24 hours after hydrogen peroxide treatment in the absence and presence of CoQ10. Activity of Caspase-3 was expressed per $\mu$ g protein. Note that the caspase-3 activity in the extract from control cells is taken as $100 \%$. Standard errors were calculated using data from three sets of separate experiments. Microsoft excel version 6.0 sofware was used to represent data and calculate standard deviation. 
Figure 15. B. Proteosome activity after hydrogen peroxide treatment
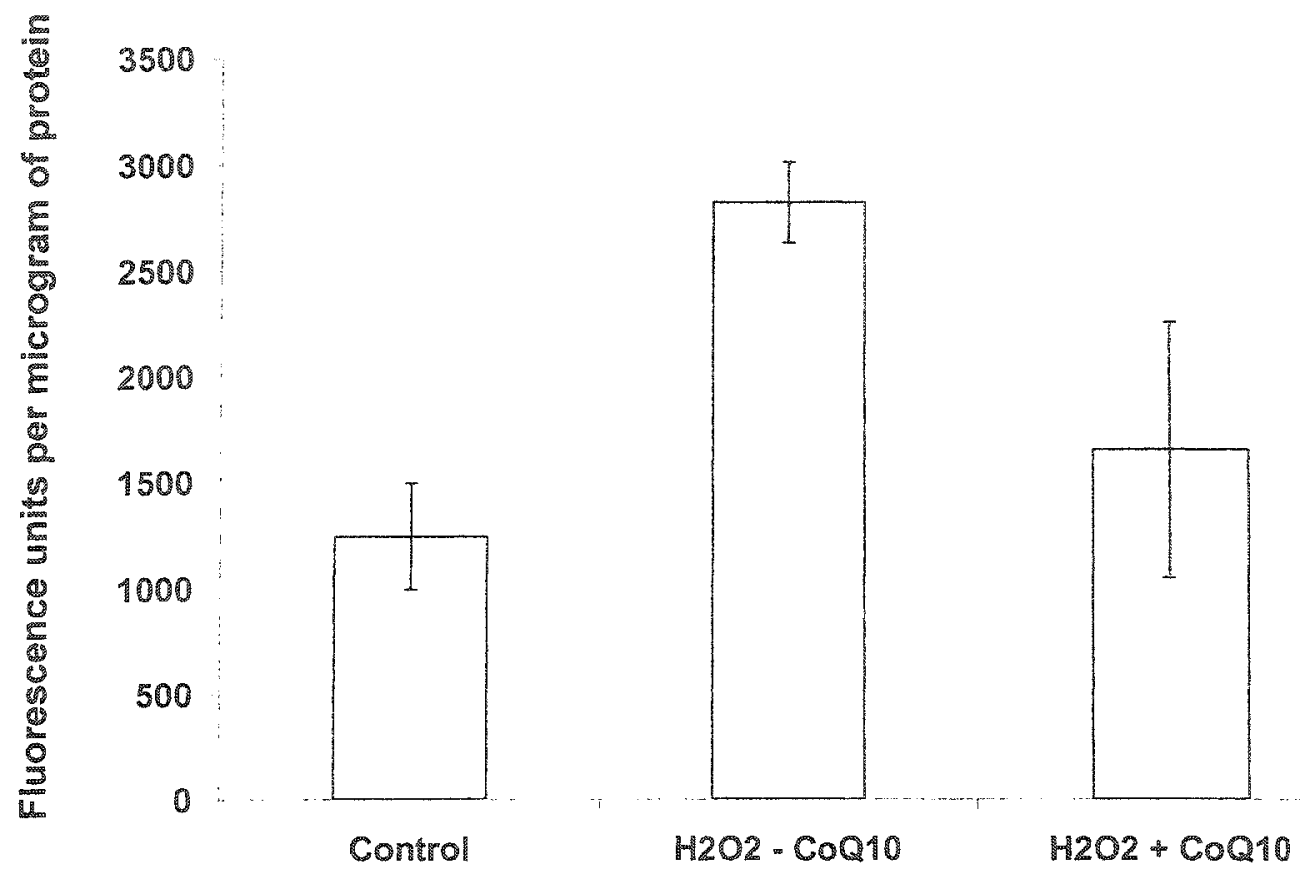

Proteasome assay was performed employing cell extracts from control and treated NT2N cells a fter 24 hours a s mentioned e arlier and expressed per $\mu \mathrm{g}$ protein. Standard errors were calculated using data from three sets of separate experiments. Microsoft excel version 6.0 software was used to represent data and calculate standard deviation. $(p<0.05)$ 
been shown previously that $\mathrm{H}_{2} \mathrm{O}_{2}$ produced in the mitochondria can be measured spectrofluorometrically by using the PHPA method (Li et al., 2003).

We monitored $\mathrm{H}_{2} \mathrm{O}_{2}$ production from mitochondria isolated from control and treated SH-SY5Y cells 24 hours after inducing oxidative stress as described in Materials and Methods. Results obtained indicated that mitochondria isolated from treated cells generated more $\mathrm{H}_{2} \mathrm{O}_{2}$ as compared to untreated cells. Furthermore, we observed that the increase in the production of ROS from the mitochondria after inducing oxidative stress was inhibited by $\mathrm{COQ}_{10}$ pre-treatment (Figure 16).

\subsection{9. $\mathrm{CoQ}_{10}$ prevents the collapse of mitochondrial membrane potential}

It has been established that cells are capable of $\mathrm{CoQ}_{10}$ internalization when $\mathrm{COQ}_{10}$ is added to tissue culture media in an aqueous solution. Increase in $\mathrm{COQ}_{10}$ content in the mitochondria as well as in membranes has been reported (Sandhu et al., 2003). Since $\mathrm{CoQ}_{10}$ is present in the mitochondrial membrane, it may stabilize the mitochondrial membrane and prevent it from collapsing under oxidative stress. In order to evaluate this possibility, mitochondrial membrane potential was studied using Mitotracker Red dye. Mitotracker Red is a membrane permeable dye and fluoresces brightly once it enters the mitochondria. If the mitochondrial membrane potential is decreased then the fluorescence 
Figure 16. Production of mitochondrial reactive oxygen species after hydrogen peroxide treatment
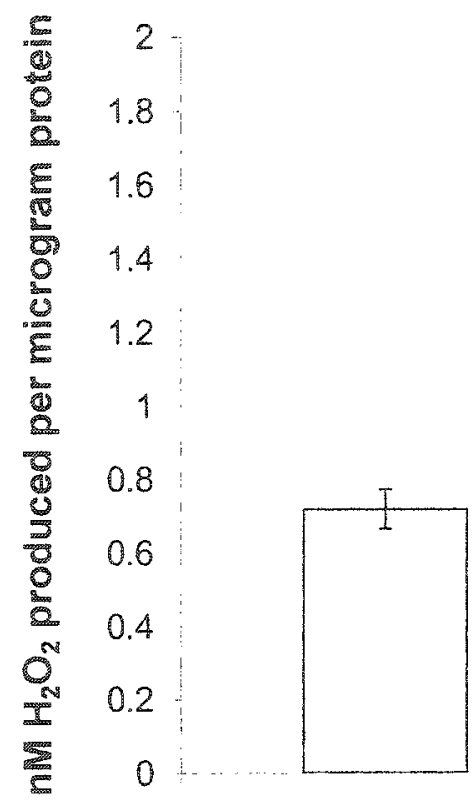

Control

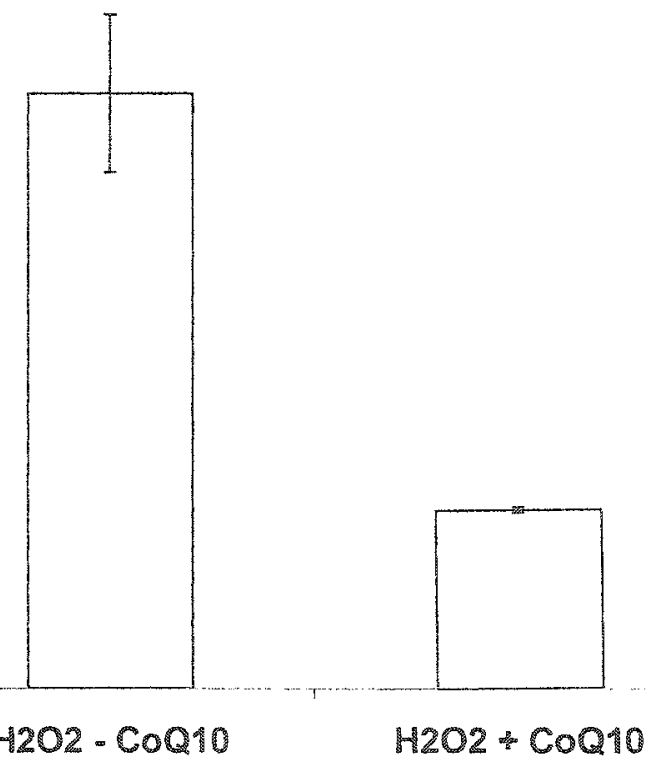

Mitochondria were isolated from $\mathrm{SH}-\mathrm{SY} 5 \mathrm{Y}$ cells after 24 hours of $\mathrm{H}_{2} \mathrm{O}_{2}$ treatment in presence and absence of $\mathrm{CoQ}_{10}$. Hydrogen peroxide generated by the mitochondria was measured using PHPA as mentioned in Materials and Methods. Hydrogen peroxide production was expressed per $\mu g$ of total mitochondrial protein. Microsoft excel version 6.0 software was used to represent data and calculate standard deviation. Standard errors were calculated using data from three sets of separate experiments. 
is diffused. SH-SY5Y cells were stained with Mitotracker Red 24 hours after treatment, as described previously. As shown in figure 17.B, a decrease in the mitochondrial membrane potential after treatment was evident. But $\mathrm{CoQ}_{10}$ prevented the mitochondrial membrane potential collapse after induction of oxidative stress (Figure $17 \mathrm{C}$ ), suggesting that $\mathrm{COQ}_{10}$ stabilizes the mitochondrial membrane. Control cells are seen in figure 17A. Similar results were obtained using NT2 astrocytes (Figures 17D, 17E \& 17F).

\subsubsection{CoQ 10 restores ATP production in cells under oxidative stress}

Neurons depend on oxidative phosphorylation in the mitochondria in order to generate ATP. To determine the ATP content following oxidative stress, SHSY5Y cells were grown, differentiated and treated with $\mathrm{H}_{2} \mathrm{O}_{2}$ as described in materials and methods. Mitochondria were isolated from SH-SY5Y cells 24 hours after treatment and luciferin-luciferase assay was used to measure ATP production. Results showed that there was a decrease in the ATP levels following oxidative stress. However, $\mathrm{COQ}_{10}$ pretreatment prevented the loss in ATP production following oxidative stress significantly (Figure 18). Each of the last three experiments- inhibition of ROS production from isolated mitochondria, restoration of mitochondrial membrane potential and ATP production from isolated mitochondria suggested that $\mathrm{CoQ}_{10}$ functions at the mitochondrial level, to protect neuronal cell death due to oxidative stress. 
Figure 17. Mitochondrial membrane potential in differentiated SH-SY5Y

cells following hydrogen peroxide treatment

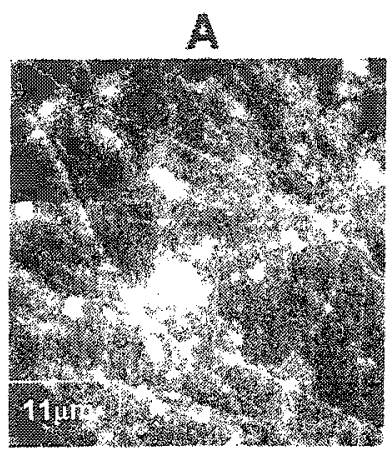

Control

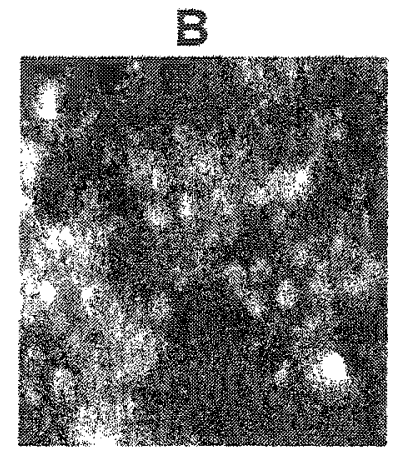

$\mathrm{H}_{2} \mathrm{O}_{2}-\mathrm{CoQ}_{10}$

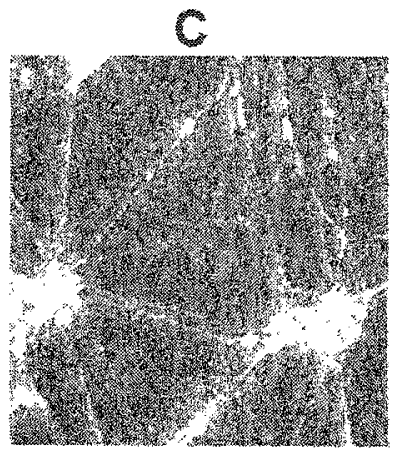

$\mathrm{H}_{2} \mathrm{O}_{2}+\mathrm{CoQ}$

SH-SY5Ycells were treated with $\mathrm{H}_{2} \mathrm{O}_{2}$ for 1 hour in absence or presence of $\mathrm{COQ}_{10}$, after which cells were washed with fresh media and incubated at $37^{\circ} \mathrm{C}$ for 24 hours and then stained with Mitotracker Red dye as mentioned in materials and methods. Pictures were taken at a magnification of $400 \times$ using Leica DM IRB microscope. Figure A represents control cells while $B$ represents $\mathrm{H}_{2} \mathrm{O}_{2}$ treated cells in the absence of $\mathrm{CoQ}_{10}$ while $\mathrm{C}$ represents cells treated in the presence of $\mathrm{COQ}_{10}$. 
Figure 17. Mitochondrial membrane potential in differentiated NT2 astrocytes following hydrogen peroxide treatment

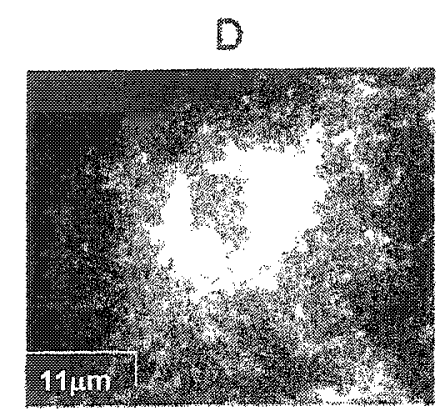

Control

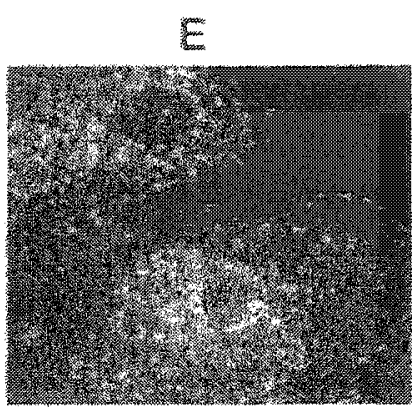

$\mathrm{H}_{2} \mathrm{O}_{2}-\mathrm{CoQ}_{10}$

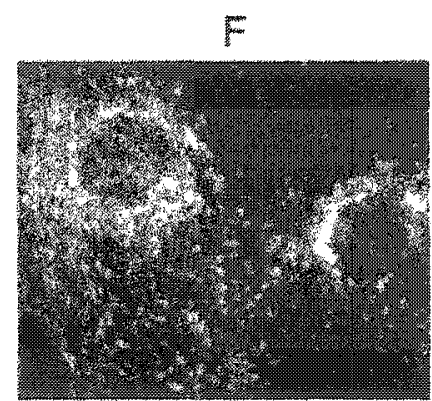

$\mathrm{H}_{2} \mathrm{O}_{2}+\mathrm{CoO} 10$

NT2 astrocytes were treated with $\mathrm{H}_{2} \mathrm{O}_{2}$ for 1 hour in absence or presence of $\mathrm{COQ}_{10}$, after which cells were washed with fresh media and incubated at $37^{\circ} \mathrm{C}$ for 24 hours and then stained with Mitotracker Red dye as mentioned in Materials and Methods. Pictures were taken at a magnification of $400 \times$ using Leica DM IRB microscope. Figure D represents untreated cells while $E$ represents $\mathrm{H}_{2} \mathrm{O}_{2}$ treated cells in the absence of $\mathrm{CoQ}_{10}$ while $\mathrm{F}$ represents cells treated in the presence of $\mathrm{COQ}_{10}$. 
Figure 18. Mitochondrial ATP production in SH-SY5Y cells after hydrogen peroxide treatment

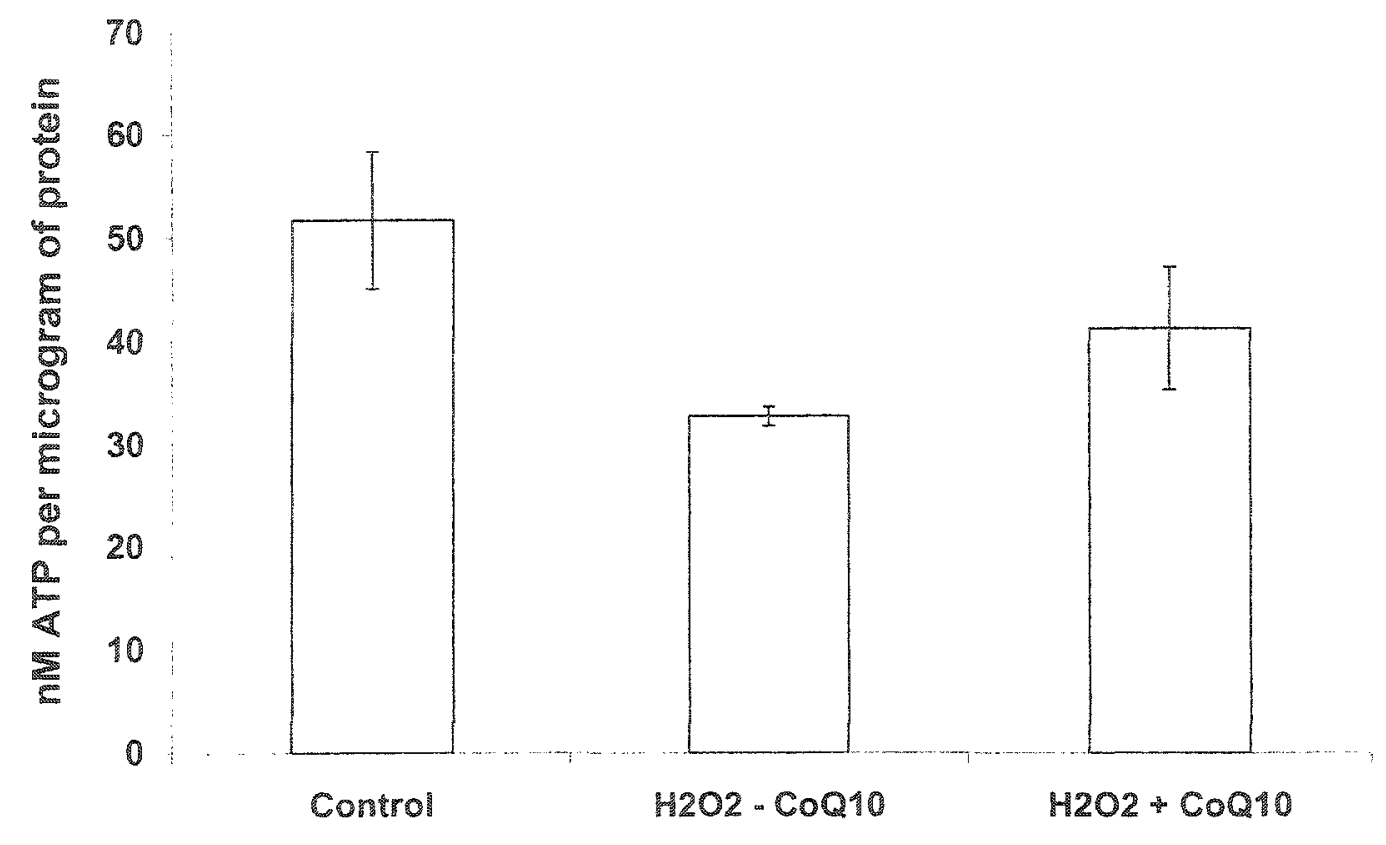

SH-SY5Y cells were treated with $\mathrm{H}_{2} \mathrm{O}_{2}$ for 24 hours in the presence and absence of $\mathrm{COQ}_{10}$ and mitochondria were isolated. Luciferin - Luciferase was used to measure ATP production. An internal ATP standard was used and ATP production was expressed per $\mu \mathrm{g}$ of total mitochondrial protein. Microsoft excel version 6.0 software was used to represent data and calculate standard deviation. Standard errors were calculated using data from three sets of separate experiments. $(p<0.05)$ 
3.2.1. Paraquat induces Oxidative Stress that can induce apoptosis in differentiated neuronal SH-SY5Y cells

Paraquat is a herbicide that has been shown to be related to development of Parkinson's disease. The structure of paraquat resembles that of MPP ${ }^{+}$and cell death induced by paraquat has been reported.

In order to study the effects of paraquat on neuronal cells, SH-SY5Y cells were grown, differentiated and treated as previously described. Cellular morphology was observed after 48 hours of paraquat treatment. Morphological changes were evident, including beading on neurites and rounding up of the cells, after 48 hours of paraquat treatment (Figure 19B). Control cells did not have evident morphological changes as indicated by figure 19 A. Nuclear condensation, a characteristic feature of apoptosis was clearly observed after treatment as shown in figure 208, whereas the nuclei of control cells did not show nuclear condensation (Figure 20A). DNA degradation is also a characteristic feature of a poptotic cell death. A comet assay was employed to examine DNA degradation changes after treatment with paraquat. The cells treated with paraquat showed comet-like images (Figure 21B), indicating DNA damage, whereas control cells did not (Figure 21 A). All these results to strongly indicate that SHSY-5Y cells undergo apoptosis after paraquat treatment induced oxidative stress. 
Figure 19. Morphology of SH-SY5Y cells after paraquat treatment

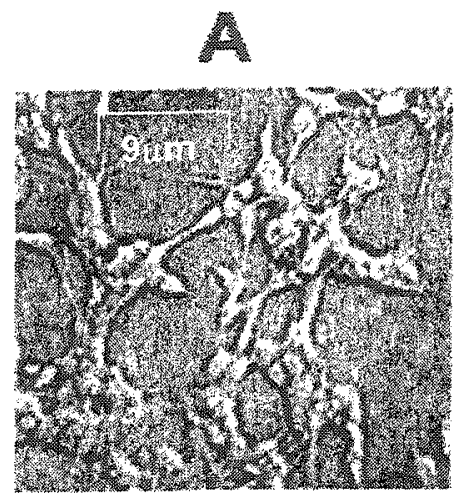

Control

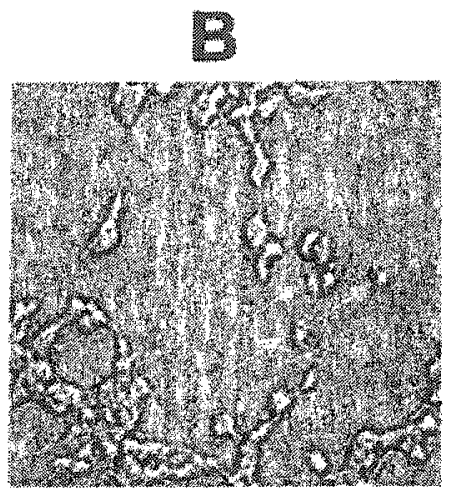

Paraquat - $\mathrm{COQ} 10$

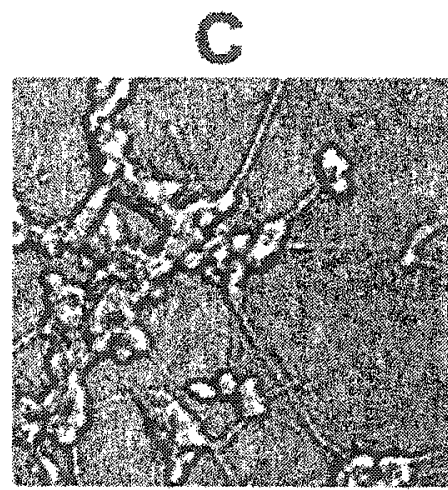

Paraquat + CoQ10

Differentiated SH-SY5Y cells were treated with $100 \mu \mathrm{M}$ paraquat in presence (C) and absence $(B)$ of $\mathrm{CoQ}_{10}$ as described in Materials and Methods. Figure $A$ depicts control neuronal cells which were not treated with paraquat. After 48 hours of treaiment, pictures were taken at $400 \mathrm{X}$ magnification using a Leica DM IRB microscope. Arrows indicate rounding up of cells. 
Figure 20. Nuclear morphology of SH-SY5Y cells after paraquat treatment

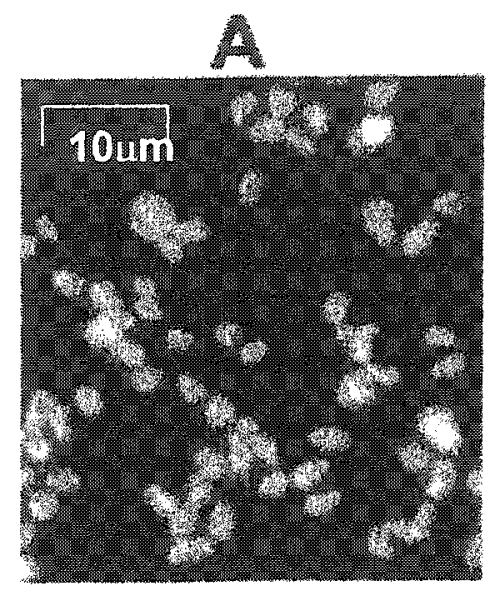

Control

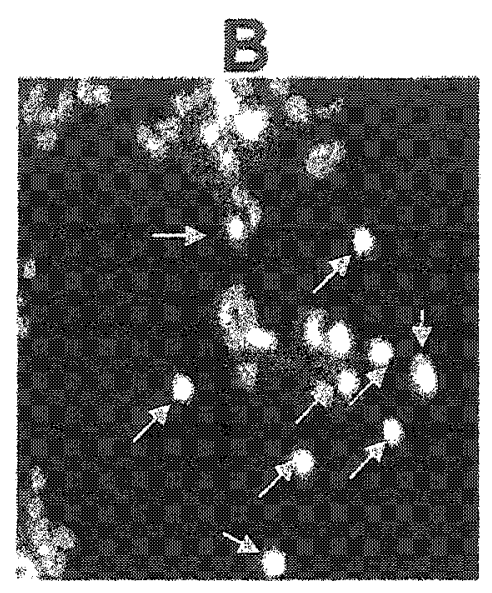

Paraquat - $\mathrm{CoQ}_{10}$

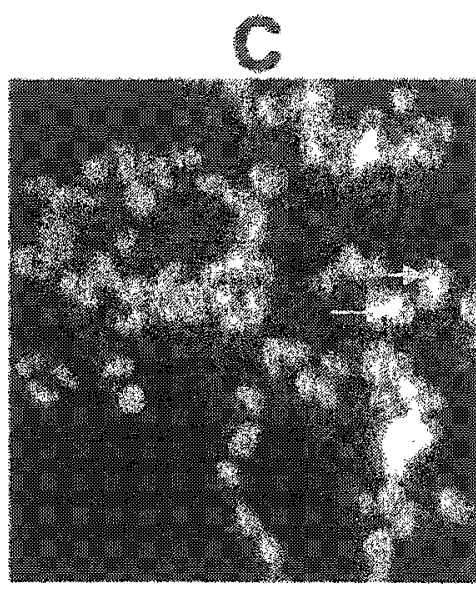

Paraquat $+\mathrm{CoQ}_{10}$

As described in methods, differentiated SH-SY5Y cells were treated with $100 \mu \mathrm{M}$ paraquat in presence $(C)$ and absence $(B)$ of $C_{0} Q_{10}$ as mentioned in Materials and Methods. Figure A depicts control neuronal cells which were not treated with paraquat. After 48 hours of treatment, Hoechst 33342 dye was applied to the cells to examine nuclear morphology. Pictures were taken at $400 \mathrm{X}$ magnification using a Leica DM IRB microscope. Nuclear condensation is evident in cells with bright, condensed and rounded nuclei and indicated by arrows. 
Figure 21. DNA degradation after paraquat treatment

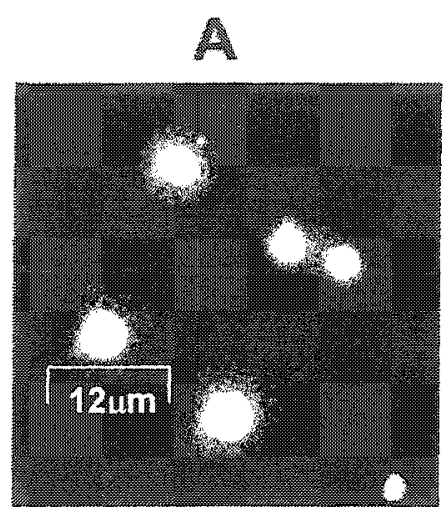

Control

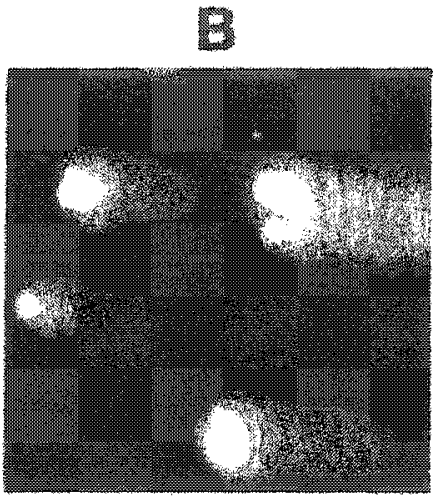

Paraquat - $\mathrm{CoQ}_{10}$

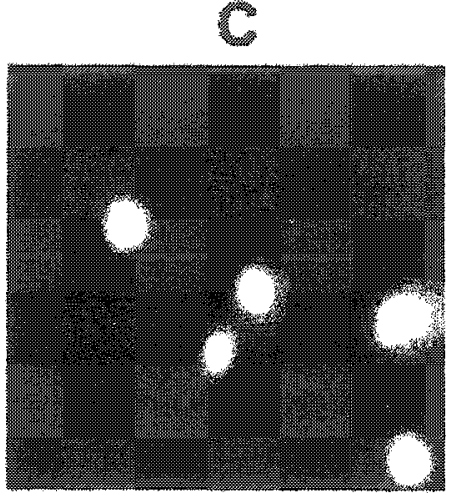

Paraquat $+\mathrm{CoQ}_{10}$

Differentiated SH-SY5Y cells were treated with $100 \mu \mathrm{M}$ paraquat in presence (C) and absence $(B)$ of $\mathrm{CoQ}_{10}$ as previously described. Figure $A$ depicts neuronal cells which were not treated with paraquat. After 48 hours of treatment, a comet assay was conducted, as described in Materials and Methods. Pictures were taken at $400 X$ magnification using a Leica DM IRB microscope. DNA degradation is indicated by comet-like images due to migration of damaged DNA during electrophoresis. 
3.2.2. Pre-ireatment with water-soluble $\mathrm{CoQ}_{10}$ protects cells from paraquat= induced apoptosis

SH-SY5Y cells were grown, differentiated and treated as described in the materials and methods section, followed by observation of the cellular morphology. After 24 hours of pre-treatment with $\mathrm{COQ}_{10}$ and 48 hours of paraquat treatment, SH-SY5Y cells did not show any apoptotic morphology (Figure 19C). Similarly the nuclear morphology (Figure 20C) indicated that the nuclear chromatin condensation was inhibited in cells pre-treated with $\mathrm{CoQ}_{10}$. Pre-treatment with $\mathrm{COQ}_{10}$ also resulted in fewer number of comet-like images (Figure 21C) as cells treated with paraquat alone, indicating less DNA damage. All these results taken together suggest that $\mathrm{COQ}_{10}$ protects $\mathrm{SH}-\mathrm{SY} 5 Y$ cells from undergoing apoptosis.

\subsubsection{Paraquat induces oxidative stress in differentiated SH-SY5Y cells and} $\mathrm{COQ}_{10}$ offers protection

In order to determine whether paraquat treatment caused oxidative stress on SH-SY5Y cells, the production of ROS was measured. ROS measurements were collected after treatment of SH-SY5Y cells as previously described. After 48 hours of paraquat treatment, cells showed a considerable raise in ROS production compared to control cells or cells pre-treated with $\mathrm{CoQ}_{10}$ as indicated by figure 22. Results have been expressed as percentage of control. 
Figure 22. Generation of reactive oxygen species after paraquat treatment

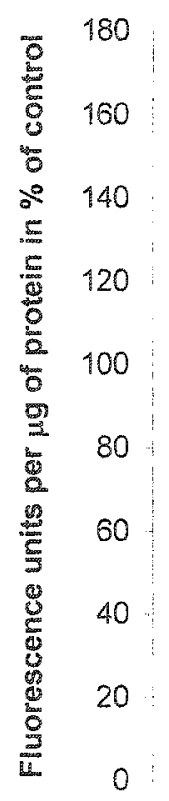

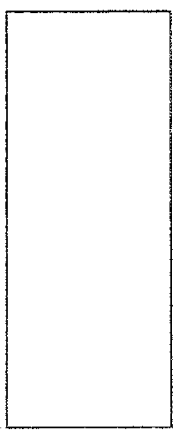

Control

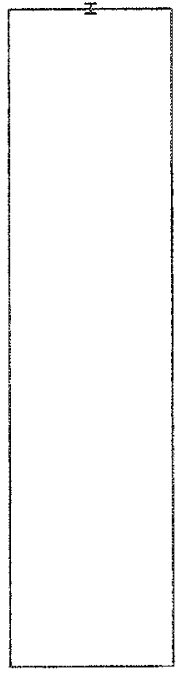

Paraquat

$-\mathrm{CoQ}_{10}$

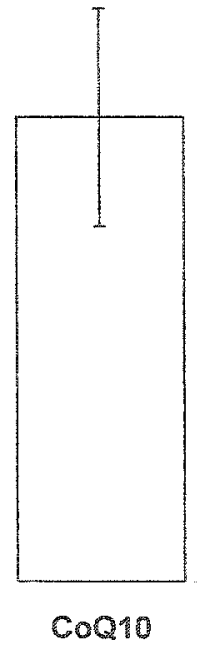

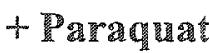

After 48 hours of paraquat treatment with differentiated SHSY-5Y cells in the absence and presence of $C O Q_{10}, D C F D A$ was used to measure total cell ROS generation, as described in Materials and Methods. Microsoft Excel Version 6.0 software was used to represent data and calculate standard deviation. Results were calculated per microgram of protein and expressed in percentage of control. Standard errors were calculated using data from three separate sets of experiments $(p<0.05)$. 


\section{CHAPTER 4}

\section{DISCUSSION}

Oxidative stress induced apoptosis has been implicated with several neurodegenerative diseases. In the present study, we have investigated the role of oxidative stress on neuronal cell death and neuro-protection by water soluble $\mathrm{CoQ}_{10}$ following $\mathrm{H}_{2} \mathrm{O}_{2}$ and paraquat induced oxidative stress.

\subsection{NT2 and SH-SY5Y cells as neuronal models}

Neurons are post-mitotic tissues. It is difficult to study the biochemical mechanisms of neurodegenerative diseases due to the lack of availability of human neurons. Human teratocarcinoma (NT2N) and Human Neuroblastoma (SH-SY5Y) cells have been used as neuronal models to study neuronal functions. Previous studies have shown that NT2 cells can be differentiated into neurons and astrocytes, and the commitment of these cells to a stable phenotype is irreversible (Sandhu et al., 2003, Guillemain et al., 2000). NT2-N cells have also been shown to survive and integrate within the host brain after transplantation and help in function recovery in animal models of stroke, Parkinson's and Huntington's disease (Sandhu et al., 2003, Hartley et al., 1999, Borlongan et al., 1998). SH-SY5Y cells can be differentiated into human neuron like cells, but the survival of these cells is dependent on BDNF and removal of BDNF leads to apoptosis in these cells. Differentiated cells express neuronal markers (Leypoldt et al., 2002, Encinas et al., 2000). Therefore the results 
obtained using the choice of these two these cell lines for the study of neuronal cell death would be more relevant to human neurodegenerative diseases.

\subsection{Induction of apoptosis by external oxidative stress}

It has been shown that oxidative stress such as $\mathrm{H}_{2} \mathrm{O}_{2}$ can induce apoptosis in cells and cultured neurons (Chang et al., 2003, Ratan et al., 1994, Enokido et al., 1990). We subjected the differentiated neuronal cells to direct oxidative stress by a brief $\mathrm{H}_{2} \mathrm{O}_{2}$ treatment. We have demonstrated that differentiated neuronal cells are very sensitive and undergo apoptosis following direct oxidative stress by $\mathrm{H}_{2} \mathrm{O}_{2}$ treatment, as clearly indicated by cellular morphology, nuclear condensation and DNA fragmentation-the characteristics features of apoptosis. It has been observed that undifferentiated NT2 or SHSY5Y cells are not sensitive to oxidative stress induced by similar concentration of hydrogen peroxide. Although $100 \square \mathrm{M} \mathrm{H} \mathrm{H}_{2} \mathrm{O}_{2}$ is not a physiological concentration during any disease, but for in vitro models, a brief exposure to100 $\mu \mathrm{M} \mathrm{H} \mathrm{H}_{2} \mathrm{O}_{2}$ causes oxidative stress.

Our results showed that indeed there was increase in ROS production after $\mathrm{H}_{2} \mathrm{O}_{2}$ treatment, a decrease in $\mathrm{GSH}$ level and increased lipid peroxidation. A decreased GSH levels and an affiliated increase in ROS during apoptosis have been reported in previous studies (Tan et al., 1998). Moreover, lipid peroxidation

is also a direct measure of oxidative stress. Our data showed an increase in lipid peroxidation upon treatment with $\mathrm{H}_{2} \mathrm{O}_{2}$. All these results taken together suggest that cells were under oxidative stress which in turn led to apoptotic cell death. 


\subsection{Oxidative stress causes mitochondrial dysfunction}

Mitochondria have been shown to play a key role in the apoptotic process. Mitochondrial control of apoptosis can be described at two important levels; one is the maintenance of ATP production. The other is mitochondrial membrane potential and mitochondrial membrane permeability for the release of certain apoptogenic factors such as cytochrome $\mathrm{C}$ into the cytoplasm. Cytochrome C can bind to pro-caspase-9 and Apaf-1 to form the apoptosome, further causing the activation caspase-3. Treatment with $\mathrm{H}_{2} \mathrm{O}_{2}$ has been shown to cause mitochondrial dysfunction (Leducq et al., 2003, Tsutsumi et al., 2002). Disruption of the mitochondrial respiratory chain can not only result in over production of ROS leading to oxidative stress, but also activation of apoptotic mediators (Bortner et al., 2002). Mitochondria actively generate ROS such as super oxide anions and hydrogen peroxide (Kannan et al., 2000). When we monitored the ROS production from mitochondria isolated from differentiated NT2N and SH-SY5Y cells after inducing oxidative stress, an increase in ROS production by after treatment occurred. Each of these experiments confirmed that oxidative stress was induced by hydrogen peroxide treatment. Increased mitochondrial ROS and caspase-3 activation also suggested mitochondrial dysfunction, following oxidative stress. 


\subsection{Neuroprotection offered by $\mathrm{COQ}_{10}$ prevents mitochondrial dysfunction and rescues cells from oxidative stress}

Coenzyme $\mathrm{Q}_{10}$ is hydrophobic and localized in the inner mitochondrial membrane. Previous studies have used oil formulations of $\mathrm{CoQ}_{10}$. Since $\mathrm{CoQ}_{10}$ is very hydrophobic, cells cannot take it up easily. Recently water soluble $\mathrm{COQ}_{10}$ containing both the oxidized and reduced forms was formulated (BorowyBorovski, US Patent No. $6,045,826)$. Water-soluble formulations of $\mathrm{CoQ}_{10}$ are readily taken up by the cells, when added to tissue culture media, making it possibie to study the mechanism by which $\mathrm{CoQ}_{10}$ offers protection against oxidative stress. An increase in $\mathrm{CoQ}_{10}$ content in the mitochondrial membranes and cell membranes has been observed in cells pre-treated with $\mathrm{CoQ}_{10}$ (Sandhu et al., 2003). Our data have shown that water soluble $\mathrm{COQ}_{10}$ can provide protection by functioning as an antioxidant against oxidative stress indicated by high ROS levels, elevated lipid peroxidation and decreased levels of GSH.

Coenzyme $Q_{10}$ carries electrons from Complex-1 and Complex-ll to Complex-III. Since it is a component of the electron transport chain, we were interested to see whether an extra amount of $\mathrm{COQ}_{10}$ would help restore mitochondrial functions $d$ uring oxidative stress. Our study h as indicated $C \circ Q_{10}$ protection at the mitochondrial level. Firstly, in the cells pre-treated with $\mathrm{COQ}_{10}$ before $\mathrm{H}_{2} \mathrm{O}_{2}$ treatment, the mitochondrial ROS was significantly low when compared to those isolated from the cells that had not been pre-treated with $\mathrm{COQ}_{10}$ before $\mathrm{H}_{2} \mathrm{O}_{2}$ treatment. Furthermore, we observed that mitochondria maintained the membrane potential in presence of $\mathrm{CoQ}_{10}$ (figures $17 \mathrm{C}, 17 \mathrm{~F}$ ). 
These observations strongly suggest that $\mathrm{CoQ}_{10}$ can act not only as an antioxidant but also to stabilize the mitochondrial membrane during oxidative stress. Another interesting observation was that mitochondria in cells treated with hydrogen peroxide in the presence of $C O Q_{10}$ remained functional and maintained ATP production at almost a normal level, led us to believe that $\mathrm{CoQ}_{10}$ may have enhanced the electron transport from complex-1 and complex-1| to complex-III. We have demonstrated $\mathrm{COQ}_{10}$ protects cells at all the different levels in the apoptotic pathway both morphologically and biochemically.

Our study demonstrates that $C o Q_{10}$ can prevent mitochondrial dysfunction during oxidative stress. Results in our lab have also shown that Bax induced ROS generation from mitochondria can be prevented by $\mathrm{CoQ}_{10}$ (Pandey et al., unpublished data).

Recent studies have focused on designing new therapeutics for protection against neurodegeneration. These include the investigation of the role of microglial activation as a target for neuro-protection (Dommergues et al., 2003), testing neuro-protective agents such as docosahexaenoic acid, nimodipine and citicoline (Hogyes et al,, 2003, Sobrado et al., 2003) and using anti-oxidants like estradiol, (Marin et al., 2003) melatonin (Erol et al., 2003) and vitamin E (GarciaEstrada et al., 2003). However, Vitamin E cannot prevent mitochondrial depolarization, cytochrome c release and caspase- 9 activation induced by apoptotic stimuli (Papucci et al., 2003). It is not clearly known how hydrogen peroxide causes mitochondrial dysfunction. One of the hypotheses is that it may 
cause distinct changes including lipid peroxidation and these changes may trigger a cascade.

\subsection{Mechanism of CoQ10 neuroprotection}

Recent reports have suggested that the permeability transition pore (PTP) in the mitochondria harbors a ubiquinone binding site and is regulated by complex-1 of the mitochondrial respiratory chain (Papucci et al, 2003, Waiter et al., 2002, Petronilli et al., 2001, Walter $L$ et al., 2000, Fontaine $E$ et al., 1999, Fontaine $E$ et al., 1998). Our next steps would include considering whether PTP are involved in the pathway by using PTP inhibitors and also to see how CoQ 10 interferes at PTP level. It will also be important to see if there is any competition between Bax and COQ10 at the PTP binding sites and whether oxidatively modified protein can cause the opening of the PTP.

\subsection{Neuroprotection by $\mathrm{CoQ}_{10}$ against paraquat toxicity}

Paraquat, a non-selective herbicide which is still used in some countries, has been found to selectively kill nigrostriatal dopaminergic neurons in animal models (McCormack et al., 2002). Several investigations have revealed that environmental toxins, including paraquat, are responsible for the development of sporadic age-related Parkinsonism (Di Monte, 2002). A strong association between paraquat exposure and risk of Parkinson's disease has been reported in farmers in Tawan where paraquat is frequently sprayed in rice fields (Liou et al., 1997). Paraquat induced cell death has been reported in lung epithelial cells and 
rat PC12 cells (Capelletti et al., 1998, Fabisiak et al., 1998). One of the problems with previous animal models of paraquat-induced Parkinsonism has been its direct toxicity to the lung and liver before the behavioral symptoms of the disease appear (Onyon et al., 1987). It has been postulated that paraquat is structurally similar to MPP ${ }^{+}$, the active metabolite of MTPT, therefore the mechanism of paraquat neurotoxicity has been a ssumed to be similar (Shimizu et a I., 2001). $\mathrm{MPP}^{+}$has been shown to cause cell death in a nigral dopaminergic cell line due to increased oxidative stress (Chun et al., 2001). Previous reports have shown that paraquat mediates its genotoxic effect, partly via its capacity to generate ROS (Suntres 2002). Our results are in agreement with these reports. We have observed an increase in the total ROS production as well as mitochondrial ROS production confirming that paraquat can generate ROS.

Although vitamin $\mathrm{E}$ confers protection against paraquat-induced injuries in vitamin E-deficient animals, normal animals receive little benefit from additional pharmacologic supplementation with vitamin $E$. In a study investigating the presence of lipid peroxidation as a potential marker of sub acute toxic reaction, it was shown that vitamin $\mathrm{E}$ supplementation to humans (100-900 $\mathrm{mg}$ per day) was ineffective in protecting a gainst $p$ araquat poisoning and did not a ffect the levels of lipid peroxidation (Yasaka et al., 1986).

In conclusion, our results clearly indicate that $\mathrm{CoQ}_{10}$ offers neuroprotection at all the stages in the apoptotic pathway against oxidative stress induced by hydrogen peroxide and paraquat. Therefore, water-soluble $\mathrm{CoQ}_{10}$ is a potential 
therapeutic agent for the treatment of neurodegenerative diseases should be further explored. 


\section{FUTURE PROSPECTIVES}

How external oxidative stress causes mitochondrial dysfunction is still not clearly understood. Further investigation is required in order to establish the mechanism by which external oxidative stress causes the loss of mitochondrial function.

It would also be interesting to find out which proteins are modified by ROS. Proteomics can aid in finding the proteins modified during oxidative stress. Oxy blot analysis using mass spectrometry can be used to identify proteins that are oxidatively modified.

Water soluble $\mathrm{COQ}_{10}$ has shown to prevent isolated mitochondria from oxidative stress. However, the mechanism by which $\mathrm{COQ}_{10}$ offers neuro protection by preventing mitochondrial damage is still not clear. The mechanism by which $\mathrm{COQ}_{10}$ prevents mitochondrial dysfunction will be extremely interesting. Whether $C O Q_{10}$ can bind to PTP and thereby affect the opening and closing the pore will be a very important step in understanding the mechanism of $\mathrm{CoQ}_{10}$ neuro protection.

It would also be fascinating to study the differences in the mechanism of protection offered by $\mathrm{CoQ}_{10}$ and other anti-oxidants like Vitamin $E$.

All the experiments mentioned here have been performed at the cellular level. It is very essential to see how $\mathrm{CoQ}_{10}$ functions in vivo brain level. Preliminary results in our lab showed that normal rats fed with water soluble 
$\mathrm{COQ} 10$ showed a systematic reduction in oxidative stress in the brain and liver as shown by higher GSH levels and lower levels of lipid peroxidation as compared to rats that were not fed with $\mathrm{COQ}_{10}$. However, further investigation is required to study the properties of water soluble $\mathrm{COQ}_{10}$ as a neuro-protective agent. Moreover it will be very interesting to see the effect of oxidative stress and inhibition by water soluble $\mathrm{COQ}_{10}$ on behaviour of these animals. 


\section{REFERENCES}

1. Amaiz, S., L., Coronel, M., F., and Boveris A. (1999) Nitric oxide, superoxide, and hydrogen peroxide production in brain mitochondria after haloperidol treatment. Nitric Oxide $3: 235-243$.

2. Ashkenazi, A., Dixit, V., M. (1998) Death receptors: signaling and modulation. Science 281:1305-1308.

3. Baker, M., A., Cerniglia, G., J., Zaman, A. (1990) Microtiter plate assay for the measurement of glutathione and glutathione disulfide in large numbers of biological samples. Anal. Biochem. 190(2):360-365.

4. Beal, M., F. (1999) Mitochondria, NO and neurodegeneration. Biochem. Soc. Symp $66: 43-54$

5. Behl, C., Moosmann, B. (2002) Antioxidant neuroprotection in Alzheimer's disease as preventive and therapeutic approach. Free Radic. Biol. Med. $33(2): 182-91$

6. Behl, C. (1999) Alzheimer's disease and oxidative stress: implications for novel therapeutic approaches. Prog. Neurobiol. 57:301-323.

7. Benedict, M., A., Hu, Y., Inohara, N. et al. (2000) Expression and functional analysis of Apaf-1 isoforms. Extra Wd-40 repeat is required for cytochrome c binding and regulated activation of procaspase-9. J. Biol. Chem. $275: 8461-8468$

8. Betteridge, D., J. (2000) what is oxidative stress? Metabolism 49:3-8. 
9. Beyer, R., E., Segura-Aguilar, J., Di Bernardo, S., Cavazzoni, M., Fato, R., Fiorentini, D., Galli, M., C., Setti, M., Landi, L., and Lenaz, G. (1996) Proc. Natl. Acad. Sci. USA 93:2528-2532.

10. Borlongan, C., V., Tajima, Y., Trojanowski, J., Q., Lee, V., M., Y., Sanberg, P. (1998) Transplantation of cyopreserved human embryonal carcinoma-dervied neyrons NT2N cells promotes functional recovery in ischemic rats . Exp. Neurol. 149:310-321.

11.Borowy-Borowski, H., Sikorska, M., Walker, P., R. Water soluble composition of bioactive lipophilic compounds. US Patent No. 6,045, 826.

12. Bortner, C., D., Cidlowski, J., A. (2002) Cellular mechanism for the repression of apoptosis. Annu. Rev. Pharmacol. Toxicol. 42:259-81.

13.Boulakia, C., A., Chan, G., Ng. F., W., Teodoro, J., G., Branton, P., E., Nicholson, D., W., et al. (1996) Bcl-2 and adenovirus E1B 19 kDA protein prevent E1A-induced processing of CPP32 and cleavage of poly (ADPribose) polymerase. Oncogene 12:529.

14. Boveris, A., Chance, B. (1973) The mitochondrial generation of hydrogen peroxide. General properties and effect of hyperbaric oxygen. Biochem. J. 134: $707-716$

15.Burdon, R., H. (1996) Control of cell proliferation by reactive oxygen species. Biochem. Soc. Trans. 24:1028-1032

16. Burdon, R., H. (1995) Superoxide and hydrogen peroxide in relation to mammalian cell proliferation. Free Radic. Biol. M 18:775-794. 
17. Butterfield, D., A., Koppal, T., Howard, B., Subramaniam, R., Hall, N., Hensley, K., Yatin, S., Allen, K., Aksenov, M., Aksenova, M., and Carney, J. (1998) Structural and functional changes in proteins induced by free radical-mediated oxidative stress and protective action of the antioxidants N-tert-butyl-alpha-phenylnitrone and vitamin E; Ann. N. Y. Acad. Sci. 854: $448-462$.

18. Cappelletti, G., Maggioni, M., G., Maci, R. (1998) Apoptosis in human lung epithelial cells: triggering by paraquat and modulation by antioxidants. Cell Biol. Int. $22(9-10): 671-678$.

19.Carmody, R., J., and Cotter, T., G. (2000) Oxidative stress induces caspase-independent retinal apoptosis in vitro. Cell Death Differ, 7:282291.

20. Casciola- Rosen, L., Nicholson, D., W., Chong, T., Rowen, K., R., Thornberry, N., Miller, D., K., et al. (1996) Apopain/ CP32 cleaves proteins that are essential for cellular repair: a fundamental principle of apoptotic death. J. Exp. Med. 183: 1957-64.

21. Casciola-Rosen, L., Miller, D., K., Anhalt, G., J., Rosen, A. (1994) Specific cleavage of the $70 \mathrm{kDa}$-protein component of the U1 small nuclear ribonucleoprotein is a characteristic biochemical feature of apoptotic cell death. J. Biol. Chem. 269:30757-60.

22. Cereser, C., Boget, S., Parvaz, P., Revol, A.( 2001) Thiram-induced cytotoxicity is accompanied by a rapid and drastic oxidation of reduced glutathione with consecutive lipid peroxidation and cell death. Toxicology 
$163: 153-162$.

23. Chance, B., Sies, A., Boveris, A. (1979) Hydroperoxide metabolism in mammalian organs. Physiol. Rev. 237:408 414.

24. Chandra, D., Lui, J., W., Tang, D., G. (2002) Early mitochondrial activation and cytochrome c up-regulation during apoptosis. J. Biol. Chem. $277.50842-50854$.

25. Chandra, J., Samali, A., Orrenius, S. (2000) Triggering and modulation of apoptosis by oxidative stress. Free Radic. Biol. Med 29:323-333.

26.Chang, D., J., Lim, C., S., Lee, S., H., Kaang, B., K. (2003) Hydrogen peroxide modulates $\mathrm{K}^{+}$ion currents in cultured Aplysia sensory neurons. Brain Research 970:159-168.

27. Chernyak, B., V., Bernardi, P. (1996) The mitochondrial permeability transition pore is modulated by oxidative agents through both pyridine nucleotides and glutathione at two separate sites. Eur J Biochem 238:623-630.

28. Chinnaiyan, A., M., Orth, K., O'Rouke, K., Duan, H., Poirier, G., G., Dixit, V., M. (1996) Molecular ordering of the cell death pathway: Bcl-2 and Bclxl function upstream of the CED-3 like apoptotic proteases. J. Biol. Chem. $271: 4473$.

29. Chittenden, T., Flemigton, C., Houghton, A., B., Ebb, R., G., Gallo, G., J., Elangovan, B., Chinnadurai, G., Lutz, R., J. (1995) A conserved domain in Bak, distinct from $\mathrm{BH} 1$ and $\mathrm{BH} 2$ mediates cell death and protein binding functions. EMBO J 14 (22):5589-5596. 
30. Christen Y. (2000) Oxidative stress and Alzheimer's disease. Am. J. Clin. Nutr. 71:6215-6295.

31. Chun, H., S., Gibson, G., E., DeGiorgio, L., A., Zhang, H., Kidd, V., J., Son, J., H. (2001) Dopaminergic cell death induced by MPP(+), oxidant and specific neurotoxicants shares the common molecular mechanism. J Neurochem. 76 (4):1010-1021.

32. Cohen, G., M. (1997) Caspases: the executioners of apoptosis. Biochem. J. $326: 1-16$.

33. Corasoniti, M., T., Strongoli, M., C., Roteroti, D., Bagetta, G., Nistico, G. (1998) Paraquat: a useful tool for the in vivo study of mechanisms of neuronal cell death. Pharmacol. Toxicol. 83:1-7.

34.Coyle, J., T., Puttafarcken, P. (1993) Oxidative stress, glutamate and neurodegenerative disorders. Science 262:689-695.

35. Cryns, V., and Yuvan, J. (1998) Proteases to die for. Genes Dev.12:155170

36.Desagher, S., Martinou, J., C. (2000) Mitochondria as the central control point of apoptosis. Trends Cell Biol 10:369-377.

37. Di Monte, D., A., Lavasani, M., Manning-Bog, A., B. (2002) Environmental factors in Parkinson's disease. Neurotoxicology 23:487-502.

38.Dommergues, M.,A., Plaisant, F., Verney, C., Gressens, P. (2003) Early microglial activation following neonatal excitotoxic brain damage in mice: a potential target for neuroprotection. Neuroscience. 121(3):619-28. 
39.Dringen, R., Hirrlinger, J. (2003) Glutathione pathways in the brain. Biol Chem 384(4):505-16.

40.Du, C., Fang, M., Li, Y., Li, L., Wang, X. (2000) Smac, a mitochondrial protein that promotes cytochrome c-dependent caspase activation by eliminating IAP inhibition. Cell 102:33-42.

41. Earnshaw, C., W., Martins, M., L., and Kaufman, H., S. (1999) Mammalian caspases; structure, activation, substrates and functions during apoptosis. Annu. Rev. Biochem. 68:383-424.

42. Enari, M., Sakahira, H., Yokoyama, H., Okawa, K., Iwamatsu, A., Nagata, S. (1998) A caspase-activated DNase that degrades DNA during apoptosis, and its inhibitor ICAD. Nature 391: 43-47.

43. Encinas, M., Iglesias, M., Liu, Y., Wang, H., Muhaisen, A., Cena, V., Gallego, C., Comella, J., X. (2000) Sequential treatment of SH-SY5Y cells with retionoic acid and brain-derived neurotrophic factor gives rise to fully differentiated, neurotrophic factor- dependent, human neuron-like cells. Journal of Neurochemistry 75:991-1003.

44. Enokido, Y., Hatanaka, H. (1990) High oxygen atmosphere for neuronal cell culture with nerve growth factor. II. Survival and growth of clonal rat pheochromocytoma PC12h cells. Brain Research 536:23-29.

45. Ernster, L., and Dallner, G. (1995) Biochemical, physiological and medical aspects of ubiquinone function. Biochim. Biophys. Acta 1271:195-204.

46. Erol, F.,S., Topsakal, C., Ozveren, M.F., Kaplan, M., Ilhan, N., Ozercan, 1. H., Yildiz, O.,G. (2003) Protective effects of melatonin and vitamin $E$ in 
brain damage due to gamma radiation. An experimental study. Neurosurg Rev. Sep 2 [Epub ahead of print].

47. Fabisiak, J., P., Kagan, V., E., Tyurina, Y., Y., Tyurin, V., A., Lazo, J., S. (1998) Paraquat-induced phosphatidylserine oxidation and apoptosis are independent of activation of PLA2. Am. J. Physiol. 274:L793-L802.

48. Finkel, T., and Holbrook, N., J. (2000) Oxidants, oxidative stress and the biology of ageing. Nature 408 6809: 239-247.

49. Fiskum, G., Murphy, A., N., Beal, M., F. (1999) Mitochondria in neurodegeneration: acute ischemia and chronic neurodegenerative diseases. J. Cereb. Blood Flow Metab. 19:351-369.

50.Fleury, C., Mignotte, B., Vayssiere, J., L. (2002) Mitochondrial reactive oxygen species in cell death signaling. Biochemie 84:131-141.

51.Fontaine, E., Bernardi, P. (1999) Progress on the Mitochondrial Permeability Transition Pore: Regulation by Complex I and Ubiquinone Analogs J. Bioenerg. Biomembr. 31: 335-345.

52. Fontaine, E., Eriksson, O., Ichas, F., Bernardi, P. (1998) Regulation of the Permeability Transition Pore in Skeletal Muscle Mitochondria. Modulation by electron flow through the Respiratory chain Complex-1. J. Biol. Chem. 273: $12662-12668$.

53. Fontaine, E., Ichas, F., Bernardi, P. (1998) A Ubiquinone-binding Site Regulates the Mitochondrial Permeability Transition Pore J. Biol. Chem.273:25734-25740.

54. Frodovich, I. (1978) The biology of oxygen radicals. Science 201:875-880. 
55. Gajendran, N., Tanaka, K., Kamada, N. (2000) Comet assay to sense neuron fingerprint. Mutation Research 452:179-187.

56. Garcia-Estrada, J., Gonzalez-Perez, O., Gonzalez-Castaneda, R.,E., Martinez-Contreras, A., Luquin, S., de la Mora, P.,G., Navarro-Ruiz, A. (2003) An alpha-lipoic acid-vitamin E mixture reduces post-embolism lipid peroxidation, cerebral infarction, and neurological deficit in rats. Neurosci. Res. 47(2):219-24.

57. Goping, I., S., Gross, A., Lavoie, J., N., Nguyen, M., Jemmerson, R., Roth, K., et al. (1998) Regulated targeting of BAX to mitochondria. J. Cell Biol. 143:207.

58. Gores, G., J., Herman, B., Lemasters, J., J. (1990) Plasma membrane bleb formation and rupture: a common feature of hepatocellular injury. Hepatology 11: 690-698.

59. Green, D., R., Reed, J., C. (1998) Mitochondria and apoptosis. Science $281: 1309-1312$

60.Gross, A., Mc Donald, J., M., Korsmeyer, S., J. (1999) Bcl-2 family members and the mitochondria in apopiosis. Genes Dev. 13:1899-1911.

61. Guillemain, I., Alsonso, G., Patey, G., Privat, A., Chaudieu, I. (2000) Human NT2 neurons express a large variety of neurotransmission phenotypes in vitro. J. Comp. Neurology 422:380-395.

62. Gupta, S. (2003) Molecular signaling in death receptor and mitochondrial pathways of apoptosis. Int. J. of Oncology 22:15-20. 
63. Halestrap, A., P., Mc Stay, G., P., Clarke, S., J. (2002) The permeability transition pore complex: Another review. Biochimie 84:153-66.

64. Hallwell, B. (1996) Antioxidants in human health and disease. Annu. Rev. Nutr 16:33-50.

65. Halliwell, B. (1989) Free radicals, reactive oxygen species and human disease: a critical evaluation with special reference to atherosclerosis. Br.J. Exp. Pathol. 70: 737-757.

66. Halliwell, B. (1987) Oxidants and human disease: some new concepts. FASEB J. 4:358-364.

67. Harris, M., H., Thompson, C., B. (2000) The role of Bcl-2 family in the regulation of outer mitochondrial membrane permeability. Cell Death Differ. 7:1182-91.

68. Hertley, R., S., Margulis, M., Fishman, P., S., Lee, V., M., Tang, C., M. (1999) Functional synapses are formed between human Ntera 2 (NT2N, hNT) neurons grown on astrocytes. J. Comp. Neurol. 407: 1-10.

69. Haslett, C. (1992) Resolution of acute inflammation and role of apoptosis in the tissue fate of granulocytes. Clin. Sci. (Colch) 83: 639-648.

70. Hirsch, T., Marzo, I., Kroemer, G. (1997) Role of the mitochondrial permeability transition pore in apoptosis. Bio. Sci. Rep. 17:67-76.

71. Hogyes, E., Nyakas, C., Kiliaan, A., Farkas, T., Penke, B., Luiten, P., G., M. (2003) Neuroprotective effect of developmental docosahexaenoic acid supplement against excitotoxic brain damage in infant rats. Neuroscience 119: 999-1012. 
72. Huang, D., C., Adams, J., M., Cory, S. (1998) The conserved N-terminal $\mathrm{BH} 4$ domain of $\mathrm{Bcl}-2$ homologues is essential for inhibition of apoptosis and interaction with CED-4. EMBO.J 17 (4):1029-1039.

73. Hunter, J., J., Bond, B., L., Parslow, T., G. (1996) Functional dissection of the the human $\mathrm{BCl}-2$ protein: sequence requirements for inhibition of apoptosis. Mol. Cell. Biol. 16(3):877-883.

74. Kamata, H., and Hirata, H. (1999) Redox regulation of cellular signalling. Cell Signal 11:1-14.

75. Kannan, K., Jain, S., K. (2000) Oxidative stress and apoptosis. Pathophysiology 7:153-63.

76.Kerr, J., F., Wyllie, A., H., Currie, A., R. (1972) Apoptosis: a basic biological phenomenon with wide - ranging implications in tissue kinetics. Br. J. Cancer 26: 239-257.

77. Kim, Y., D., Won, S., K., Gwag, B., J. (2002) Analysis of mitochondrial free radical generation in animal models of neuronal disease. Free Radic. Biol. Med. 33:715-723.

78. Kitazawa, M., Anantharam, V., Kanthasamy, A., G. (2003) Dieldrin induces apoptosis by promoting caspase-3-dependent proteolytic cleavage of protein kinase $C \delta$ in dopaminergic cells: relevance to oxidative stress and dopaminergic degeneration. Neuroscience 119:45964.

79. Kothatkota, S., Azuma, T., Reinhard, C., Klipppel, A., Tang, J., Chu, K., Mcgarry, T., J., Kirschner, M., W., Koths, K., Kwiatkowski, D., J.(1997) 
Caspase-3 generated fragment of gesolin: effector of morphological change in apoptosis. Science 278(5336): 294-8.

80. Kroemer, G., Reed, J., C. (2000) Mitochondrial control of cell death. Nat. Med. 6: 513-519.

81. Kroemer, G., Zamzami, N., and Susin, S., A. (1997) Mitochondrial control of apoptosis. Immunol. Today 18:44-51.

82.Leducq, N., Bono, F., Sulpice, T., Vin, V., Janiak, P., Fur, G., L., O'Connor, S., E., Herbert, J., M. (2003) Role of peripheral benzodiazepine receptors in mitochondrial, cellular, and cardiac damage induced by oxidative stress and ischemia-reperfusion. J. Pharmacol. Exp. Ther. $306(3): 828-37$

83. Leist, M., Jaattela, M (2001) Four deaths and a funeral: from caspases to alternative mechanisms. Nat. Rev. Mol. Cell Biol.2:589-98.

84.Leist, M., Nicotera, P. (1997) The shape of cell death. Biochem. Biopys. Res. Commun. 236:1-9.

85.Lemasters, J., J., Nieminen, A., L., Qian, T., Trost, L., C., Herman, B. (1997) The mitochondrial permeability transition in toxic, hypoxic and reperfusion injury. Mol. Cell Biochem. 174:159-65.

86. Leypoldt, F., Flajolet, M., Methner, A. (2002) Neuronal differentiation of cultured human NTERA-2cl.D1 cells leads to increase expression of synapsins. Neuroscience letters 324:37-40. 
87.Li, N., Ragheb, K., Lawler, G., Sturgis, J., Rajwa, B., Melendez, J., A., Robinson, J., P. (2003) Mitochondrial complex-l inhibitor rotenone induces apoptosis through enhancing mitochondrial reactive oxygen species production. J. Biol. Chem. 278:8516-8525.

88.Li, P., Nijhawan, D., Budihardjo, I., Srinivasula, S., M., Ahmad, M., Alnemri, E., S., et al. (1997) Cytochrome $c$ and dATP - dependent formation of A paf-1 / caspase-9 complex initiates an apoptotic p rotease cascade. Cell 91:479-89.

89.Liou, H., H., Tsai, M., C., Chen, C., J., Jeng, J., S., Chang, Y., C., Chen, S., Y., Chen, R., C. (1997). Environmental risk factors and Parkinson's disease: A case control study in Taiwan. Neurology 48:1583-1588.

90.Liou, H., H., Chem, R., C., Tsai, Y., F., Chem, W., P., Chang Y C, Tsail M. C. (1996). Effects of paraquat on the substantia nigra of the Wistar rats: Neurochemical, histological and behavioral studies. Toxicol. Appl. Pharmacol. 137: 34-41.

91.Liu, X., Zou, H., Slaughter, C., Wang, X. (1997) DFF, a heterodimeric protein that functions downstream of caspase-3 to trigger DNA fragmentation during apoptosis. Cell 89(2):175-84.

92.Lotem, J., Pele-Kamar, M., Groner, Y., Sachs, L. (1996) Cellular oxidative stress and the control of apoptosis by wild-type p53, cytotoxic compounds, and cytokines. Proc. Natl. Acad. Sci. U.S.A. 93:9166-9171.

93. Macfarlane, M., Cain, K., Sun, X., M., Alnemri, E., S., Cohen, G., M. (1997) Processing/activation of at least four interleukin-1 beta converting 
enzyme-like proteases occurs during the execution phase of apoptosis in human monocytic tumour cells. J. Biol. Chem. 271:16443-6.

94. McCormack, A., L., Thiruchelvam, M., Manning-Bog, A., B. (2002) Environmental risk factors and Parkinson's disease: Selective degeneration of nigral dopaminergic neurons caused by the herbicide paraquat. Neurobiol. Dis. 10:119-127.

95. Marin, R., Guerra, B., Hernández-Jiménez, J.-G., Kang, X.L., Fraser, J. D., et. al. (2003) Estradiol prevents amyloid- $\beta$ peptide-induced cell death in a cholinergic cell line via modulation of a classical estrogen receptor. Neuroscience 121:917-926.

96. Marnett, L., J. (2000) Oxyradicals and DNA damage. Carcinogenesis $21: 361-370$.

97. Marzo, 1., Zamzami, N., Susin, S., B eutner, G., B rdiczka, D., Remy, R., Xie, Z., H., Reed, J., C., Kroemer, G. (1998) The permeability transition pore complex: a target for apoptosis regulation by caspases and bcl-2related proteins. J. Exp. Med 187:1261-1271.

98. Mates, M., Perez-Gomez, C., and Nunez de Castro, I. (1999) Antioxidant enzymes and human diseases. Clin. Biochem. 32:595-603.

99. McConkey, D., J., Hartzell, P., Nicotera, P., W yllie, A., H., Orrenius, S. (1998) Stimulation of endogenous endonuclease activity in hepatocytes exposed to oxidative stress. Toxicol. Lett. 42: 123- 130.

100. Morano, A., Jimenez-Jimenez, F., J., Molina, J., A., Antolin, M., A. (1994) Risk factors for Parkinson's disease: case control study in the 
province Caceres, Spain. Acta. Neurol. Scand. 89:164-170.

101. Naderi, J., Hung, M., Pandey, S. (2003) Oxidative stress -induced apoptosis in dividing fibroblasts involves activation of p38 MAP kinase and over-expression of Bax: Resistance of quiescent cells to oxidative stress. Apoptosis 8:91-100.

102. Nicholson, D., W. (1999) Caspase structure, proteolytic substrates, and function during apoptotic cell death. Cell Death. Differ. 6:1028-1042.

103. Nodberg, J., and Arner, E., S., J. (2001) Reactive oxygen species, antioxidants, and the mammalian thioredoxin system. Free Radic. Biol. Med. 31(11):1287-1312.

104. Orth, K., Chinnaiyan, A., M., Garg, M., Froelich, C., J., Dixit, V., M. (1996) The CED-3/ICE-like protease M ch2 is a ctivated during a poptosis and cleaves the death substrate lamin A. J. Biol. Chem. 271(28):16443-6. 105. Onyon, L., J., Volans, G., N. (1987) The epidemiology and prevention of paraquat poisoning. Hum. Toxicol. 6:19-29.

106. Pandey, S., Lopez, C., Jammu, A. (2003) Oxidative stress and activation of proteasome protease during serum deprivation- induced apoptosis in rat hepatoma cells; inhibition of cell death by melatonin. Apoptosis 8:497-508.

107. Papucci, L., Schiavone, N., Witort, E., Donnini, M., Lapucci, A., Empestini, A., Formigli, L., Orlandini, S., Z., Orlandini, G., Carella, G., Brancto, R., Capaccioli, S. (2003) Coenzyme $Q_{10}$ prevents apoptosis by 
inhibiting mitochondrial depolarization independently of its free radical scavenging property. J. Biol. Chem.278:28220-28228.

108. Petronilli, V., Penzo, D., Scorrano, L., Bernardi, P., Fontaine, E., Di Lisa, F. (2001) The Mitochondrial Permeability Transition, Release of Cytochrome $c$ and Cell Death. Correlation with the duration of pore openings in situ. J. Biol. Chem.276:12030-12034.

109. Pleasure, S., J., Lee, V., M., Y., (1993) Ntera 2 cells: a human cell line which displays characteristics expected of a human committed neuronal progenitor cell. J. Neurosci. Res. 35:585-602.

110. Pleasure, S., J., Page, C., Lee, V., M-Y. (1992) Pure, postmitotic, polarized human neurons derived from NT2 cells provide a system for expressing exogenous proteins in terminally differentiated neurons. J. Neurosci. Res. 12:1802-1815.

111. Piantadosi, C., A., Zhang, J. (1996) Mitochondrial generation of reactive oxygen species after brain ischemia in the rat. Stoke 27:327-331.

112. Ratan, R., R., Murphy, T., H., Baraban, J., M. (1994) Oxidative stress induces apoptosis in embryonic cortical neurons. J. Neurochem. 62:376379.

113. Ray, G., and Husain, A., S. (2002) Oxidants, antioxidants and carcinogenesis. Indian J Exp Biol. 40(11):1213-32.

114. Rhee, S., G. (1999) Redox signaling: hydrogen peroxide as intracellular messenger. Exp. Mol. Med. 31:53-59 
115. Richter, C. (1993) Pro-oxidants and mitochondrial Cat ${ }^{2}$ : their relationship to apoptosis and oncogenesis. FEBS Lett. 325(1-2):104-7.

116. Rodgers, K., J., Dean, R., T. (2003) Assessment of proteasome activity in cell lysates and tissue homogenates using peptide substrates. Int. $\mathrm{J}$. Biochem. Cell. Biol. 35(5): 716-27.

117. Sanders, S., P., Zweier, J., L., Kuppuswamy, P., Harrison, S., J., Bassett, D., J., Gabrielson, E., W., Sylvester, J., T. (1993) Hypoxic sheep pulmonary microvascular endothelial cells generate free radicals via mitochondrial electron transport. J. Clin. Invest. 91:46-52.

118. Sandhu, J., K., Pandey, S., P., Lutkiewicz, M., R., Monette, R., Borowski, H., B., Walker, P., R., Sikorska, M. (2003) Molecular mechanisms of glutamate neurotoxicity in mixed cultures of NT2-derived neurons and astrocytes: protective effects of CoQ10. The Journal of Neuroscience Research 72:691-703.

119. A. Shimizu, K., Ohtaki, K., Matsubara, K., Aoyama, K., Uezono, T., Saito, O., Suno, M., Ogawa, K., Hayase, N., Kimura, K., Shiono, H. (2001) Carrier-mediated processes in blood-brain barrier penetration and neural uptake of paraquat. Brain Res. 906:135-142.

120. B. Shimizu, S., Eguchi, Y., Kamiike, W., Waguri, S., Uchiyama, Y., Matsuda, H., et al. (1996) Retardation of chemical hypoxia-induced necrotic cell death by $\mathrm{BCl}-2$ and ICE inhibitors. Possible common steps in apoptosis and necrosis. Oncogene 12:2045.

121. Shimizu, S., Eguchi, Y., Kamiike, W., Waguri, S., Uchiyama, Y., 
Matsuda, $\mathrm{H}$., et al. (1996) $\mathrm{B} \mathrm{cl-2}$ blocks loss of mitochondrial membrane potential while ICE inhibitors act at a different step during inhibition of death induced by respiratory chain inhibitors. Oncogene 13:21.

122. Shoji, Y., Uedono, Y., Ishikura, H., Takeyama, N., and Tanaka, T. (1995) DNA damage induced by tumour necrosis factor-alpha in L929 cells is mediated by mitochondrial oxygen radical formation. Immunology $84: 543-$ 548.

123. Siesjo, B., K., Siesjo, P. (1996) Mechanisms Mechanism of secondary brain injury. Eur. J. Anaesthesiol. 13:247-268.

124. Sies, H. (1993) Strategies of antioxidant defense. Eur. J. Biochem $215: 213-219$.

125. Siraki, A., G., Pourahmad, J., Chan, T., S., Khon, S., O'Brien, P., J. (2002) Endogenous and endobiotic reactive oxygen species formation by isolated hepatocytes. Free Radical Biology \& Medicine 32:2-10.

126. Sobrado, M., López, M., G., Carceller, F., García, A., G., Roda, J., M. (2003) Combined nimodipine and citicoline reduce infarct size, attenuate apoptosis and increase bcl-2 expression after focal cerebral ischemia. Neuroscience 118:107-110.

127. Steinberg, D. (1997) Low density lipoprotein oxidation and its pathobiological significance. J. Biol. Chem. 272:20963-20966.

128. Sundaresan, M., Yu, Z., X., Ferrans, V., J., Irani, K., and Finkel, T. (1995) Requirement for generation of $\mathrm{H}_{2} \mathrm{O}_{2}$ for platelet-derived growth factor signal transduction. Science 270:296-299. 
129. Suntres, Z., E. (2002) Role of antioxidants in paraquat toxicity. Toxicology. 180(1):65-77.

130. Susin, S., A., Lorenzo, H., K., Zamzami, N., Marzo, I., Snow, B., E., Brothers, G., M., Mangion, J., Jacotot, E., Constantini, P., Loeffler, M., Larochette, N., Goodlet, D., R., Aebersold, R., Siderovski, D., P., Penninger, J., M., Kroemer, G. (1999) Molecular characterization of mitochondrial apoptosis-inducing factor. Nature 397:441-446.

131. Takahashi, A., Alnemri, E., S., Lazebnik, Y., A., Fernandes- Alnemri, T., Litwack, G., Moir, R., D., Goldman, R., D., Poirier, G., G., Kaufmann, S., H., Earnshaw, W., C. (1996) Cleavage of lamin A by Mch2 alpha but not CPP32: multiple interleukin 1 beta- converting enzyme related proteases with distinct substrate recognition properties are active in apoptosis. Proct. Natl. Acad. Sci. USA 93(16):8395-400.

132. Tan, S., Sagara, Y., Liu, Y., Maher, P., Schubert, D. (1998) The regulation of reactive oxygen species production during programmed cell death. J. Cell. Biol. 141:1423-1432.

133. Tartaglia, L., A., Ayres, T., M., Wong, G., H., Goeddel, D., V. (1994) A novel domain within the $55 \mathrm{kd}$ TNF receptor signals cell death. Cell $74: 845-53$

134. Tatton, W., G., and Olanow, C., W. (1999) Apoptosis in neurodegenerative diseases: the role of mitochondria. Biochimica et Biophysica Acta 1410:195-213. 
135. Thomberry, N., and Lazebnik, Y. (1998) Caspases: enemies within. Science 281:1312-1316.

136. Traystman, R., J., Kirsch, J., R., Koehler, R., C. (1991) Oxygen radical mechanisms of brain injury following ischemia and repurfusion. J. Appl. Physiol. 71: 1185-1195.

137. Tsutsumi, S., Tomisato, W., Takano, T., Rokutan, K., Tsuchiya, T., Mizushima, T. (2002) Gastric irritant-induced apoptosis in guinea pig gastric mucosal celis in primary culture. Biochim. Biophys. Acta 1589 (2):168-80.

138. Um, H., D., Orensteine, J., M., Wahl, S., M. (1996) Fas mediates apoptosis in human monocytes by a reactive oxygen intermediate dependent pathway. J. Immunol. 156: 3469-3477.

139. Valls, V., Castelluccio, C., Fato, R., Genova, M., L., Bovina, C., Saez, G., Marchetti, M., Parenti Castelli, G., and Lenaz, G. (1994) Biochem. Mol. Biol. Int. 33:633-642.

140. Vayssière, J., L., Petit, P., X., Risler, Y., Mignotte, B. (1994) Commitment to apoptosis is associated with changes in mitochondrial biogenesis and activity in cell lines conditionally immortalized with simian virus 40. Proct. Natl. Acad. Sci. USA 91:11752-11756.

141. Verhagen, A., M., Ekert, P., G., Pakusch, M., Silke, J., Conolly, L.,M., Reid, G., E., Moritz, R., L., Simpson, R., J., Vaux, D., L. (2000) Identification of DIABLO, a mammalian protein that promotes apoptosis by binding to and antagonizing IAP proteins. Cell 102:43-53. 
142. Villa, P., Kaufmann, S., H., and Earnshaw, W., C. (1997) Caspases and caspase inhibitors. Trends Biochem. Sci. 22:388-93.

143. Walter, L., Miyoshi, H., Leverve, X., Bernardi, P., Fontaine, F. (2002) Regulation of the mitochondrial permeability transition pore by ubiquinone analogues. Free Radic. Res. 36:405-412.

144. Wen, I., P., Fahrni, J., A., Troie, S., Guan, J., L., Orth, K., Rosen, G., D. (1997) Cleavage of focal adhesion kinase by caspases during apoptosis. J .Biol. Chem. 272(41):26056-61.

145. Yasaka, T., Okudaira, K., Fujito, H. (1986) Further studies of lipid peroxidation in human paraquat poisoning. Arc. Intern. Med. 146:681-685.

146. Yin, X., M., Oltvai, Z., Korsmeyer, S., J. (1994) BH1 and BH2 domains of $\mathrm{Bcl}-2$ are required for inhibition of apoptosis and heterodimerization with Bax. Nature 369(6478):321-323.

147. Zamzami, N., Marchetti, P., Castedo, M., Zanin, C., Vayssiere, J., L., Petit, P., X., Kroemer, G. (1995) Reduction in mitochondrial potential constitutes an early irreversible step of programmed lymphocyle death in vivo. J. Exp. Med 181: 1661-1672.

148. Zoratti, M., Szabo, I. (1995) The mitochondrial permeability transition. Biochim. Biophys. Acta 1241:139-179.

149. Zou, H., Henzel, W., J., Liu, X., Lutschg, A., Wang, X. (1997) Apaf-1, a human protein homologous to $C$. elegans CED -4 , participates in cytochrome c- dependent activation of caspase-3. Cell 90:405-13. 
150. Zou, H., Li, Y., Liu, X., Wang, X. (1999) APAF-1 .cytochrome c multimeric complex is a functional apoptosome that activates procaspase9. J. Biol. Chem. 274:11549-56.

\section{Manuscripts submitted:}

1. Somayajulu M, Hung M, Sikorska M, Borowy-Borowski H, Pandey S. Role of mitochondria in neuronal cell death induced by oxidative stress; Neuroprotection by Coenzyme $Q_{10}$. Submitted to Neurobiology of Disease in December 2003.

2. McCarthy, S., Somayajulu, M., Sikorska, M., Borowy-Borowski, H., and Pandey, S. Paraquat induces oxidative stress and neuronal cell death; Neuro-protection by water soluble Coenzyme Q10. Submitted to Toxicology and Applied Pharmacology in December 2003. 